\title{
Fen Bilimleri Dersi Kapsamında Teknoloji Uygulamaları ve Tasarımına İlişkin Sınıf Öğretmenlerinin Görüşleri
}

Eser ÜLTAY, Yrd.Doç.Dr., Giresun Üniversitesi Eğitim Fakültesi, eserultay@gmail.com

Şule Merve ULUDÜZ,Yüksek Lisans Öğrencisi, Giresun Üniversitesi, sulemerveuluduz@gmail.com

Öz: Bu çalışmada amaç, öğrencilerin fene ve teknolojiye olan tutumları üzerinde büyük bir etkiye sahip olan sınıf öğretmenlerinin, fen ve teknoloji okuryazarı yetiştirmede önemli bir yeri olan teknoloji uygulamaları ve tasarımlarına ilişkin görüşlerini almaktır. Özel durum yönteminin kullanıldığı bu çalışmada veriler, araştırmacılar tarafından hazırlanmış olan 9 temel sorunun yer aldığı yarı yapılandırılmış mülakat tekniğiyle toplanmıştır. Veriler gerekli indirgemeler yapıldıktan sonra tablolar halinde sunulmuştur. Elde edilen veriler ışığında sınıf öğretmenlerinin teknoloji uygulamaları ve tasarımlarına olumlu baktıkları ve sınıf içi ders etkinliklerinde mutlaka yer verilmesi gerektiği ancak çeşitli nedenlerden dolayı (zamanın kısıtlı olması, malzeme yetersizliği vb.) sınıflarında bu tür uygulamaları çok gerçekleştiremedikleri tespit edilmiştir. Bu tespitler doğrultusunda, ilkokulların, öğretmenlerin ve öğrencilerin ihtiyaç duyabileceği öğretim teknolojileri ile donatılması ve mevcut olan 3 saatlik fen bilimleri dersi ders saati sayısının arttırılması yönünde önerilerde bulunulmuştur.

Anahtar Kelimeler: fen bilimleri dersi, öğretmen görüşleri, teknoloji uygulamaları, teknoloji tasarımları

\section{Primary Teachers' Opinion on Technological Practices and Designs in the Scope of Science Lessons}

\begin{abstract}
The aim of this study is to take primary teachers' opinion that have strong effect on students' manners towards science and technology, in regard to the technological practices and designs which have an important role on raising literates of science and technology. In this study where method of case study has been used, data have been collected in accordance with semi-structured interview technique having 9 main problems prepared by researchers. Data have been displayed after required reductions have been applied. The fact that classroom teachers take a bright view of technological practices and designs and they cannot use practices which definitely need to be included but for various reasons (lack of time, equipment failure, etc.), has been ascertained in light of the obtained data. In accordance with these findings, suggestions on the issues that primary schools need to be equipped with educational technology which school teachers and students require and 3 hours of science lesson's teaching hours need to be increased, have been made.
\end{abstract}

Key Words: science lessons, teachers' opinions, technological practices, technological designs. 


\section{GíRiş}

Teknoloji insanın var olduğu günden bu yana gelişmekte ve ilerlemekte olan bir alan olup insanın yaşadığı çevreyi istek ve ihtiyaçlarına göre şekillendirmesidir. Çağımız gereksinimlerini karşılamak ve öğrencilerimizi geleceğe daha iyi hazırlamak adına nasıl düşünecekleri, nasıl öğrenecekleri ve bu konuda gerekli teknolojiyi kullanabilme konusunda bilinçli yetiştirmek gerekmektedir (Dönmez Usta, 2011, 2015; Weis, 1999). Günümüz intiyaç ve isteklerinin artmasıyla birlikte teknolojik gelişmeler hız kazanmış ve bu alandaki çalışmaların öneminin artmasıyla birlikte teknoloji okuryazarlığı da önemli bir nitelik haline gelmiştir (Kahyaoğlu, 2011). Toplumsal hayatımızın her alanında etkili olan teknoloji, eğitim kurumlarının yapı ve işlevlerini etkilemekte ve buna bağlı olarak endüstri, ekonomi ve iletişim gibi birçok toplumsal yapı eğitim kurumlarından teknolojiyi kullanabilen bireyler yetiştirmelerini beklemektedir (Akpınar, 2003). Bu sebeple günümüz teknoloji dünyasına uyum sağlayabilen teknoloji okuryazarı bireylerin yetiştirilmesi önemli bir gerekliliktir. Fen ve teknoloji okuryazarı olan bir kişide bazı niteliklerin bulunması gerekmektedir. Bunlar, bilimin doğasını anlar, temel fen kavramlarını bilir ve buna bağlı olarak problemleri çözerken ve karar verirken bilimsel süreç becerilerini kullanır; fen-teknoloji-toplum-çevre etkileşimini anlar; bilimsel ve teknik psikomotor becerileri geliştirir; bilimsel tutum ve değerlere sahiptir (Öz, 2007). Toplumsal sistemlerde, teknoloji uygulamaları kadar teknoloji tasarımları da, günümüz dünyasını şekillendirmede etkilidir. Örneğin, 2000'li yılların başında kullandığımız disketlerin hafıza kartlarına dönüşmesi daha fazla bilgiyi daha küçük alanlarda depolayabilmemize olanak vermiş ve hayatımızı kolaylaştırmıştır. Tasarım teknolojinin merkezidir (Aydın ve Karaa, 2013). Teknoloji tasarımı zihinde var olan hayallerin nesneye uyarlanmasıdır (Çepni, Ayvacı ve Bacanak, 2012). Bu bağlamda teknolojiyi kullanabilen bireylerin yanında teknoloji tasarımları da yapabilen, yaratıcı düşünebilen bireyler toplumun kalkınma ve refahında önemli bir role sahiptir.

Tüm eğitim sistemlerinin temel amaçları, gelişen toplumun beklentilerine uygun niteliklerde bireyler yetiştirebilmektir (Anagün, 2011). Eğitimin hedeflerinden biri de toplumun intiyaçları yönünde bireyler yetiştirmek olduğuna göre, bilgi toplumlarının özelliği göz önüne alınarak, bilgi çağına uygun bireyler yetiştirme zorunluluğu ortaya çıkmıştır (Aydın, 2003). Bu bağlamda fen okuryazarlığı kavramının önemine Uluslararası Öğrenci Değerlendirme Programı (PISA) 2015 çerçeve metninde şu şekilde vurgu yapmıştır:

\footnotetext{
"Insanlık yeterli su ve yiyecek sağlamak, salgın hastalıkları kontrol etmek, yeterli enerji üretmek ve iklim değişikliğine uyum sağlamak gibi zorluklarla karşı karşıya kalırken fen okuryazarlığı hem ulusal hem de uluslararası seviyede önem kazanmaktadır. ... Tüm bu sorunlarla başa çıkmak bilim ve teknolojinin ciddi katkısını gerektirir. Avrupa Komisyonu'nun da belirttiği gibi, bilim ve teknolojiyle ilgili etik ve politik sorunlar, gençler belli bir bilimsel farkındalığa sahip olmadan bilinçli bir tartışmaya maruz kalamaz." (OECD, 2013, s.3).
}

$\mathrm{Bu}$ sebeple fen ve teknoloji okuryazarı bireylerin yetişmesinde okullara büyük görev düşmektedir. Özellikle birçok beceri, davranış ve tutumun temellerinin atıldığı ilkokullar bu anlamda önem kazanmaktadır. Teknolojinin temeli fene dayanmaktadır. Bu sebeple fen ve teknoloji okuryazarı bireyler yetiştirmek için gerekli olan derslerden bir tanesi de fen bilimleri dersidir. Bu ders yaşamın her alanında bireylerin karşısına çıkacak bilgi ve becerileri kapsamaktadır (Bağdatı,2005). Fen okur-yazarlığı, çağdaş fen programlarının vazgeçilmez amacıdır (AAAS, 1993). Fen dersinin amaçlarından biride teknoloji okuryazarı bireyler yetiştirmektir (Özdemir, 2010; Bahar, Keleş ve Koçakoğlu, 2009). 2012-2013 Eğitim öğretim yılıyla birlikte uygulanmaya başlayan $4+4+4$ sistemiyle, önceki senelerde 4 . sınıfta başlayan fen bilimleri dersi 3.sınıftan itibaren verilmeye başlanmıştır (Milli Eğitim Bakanlığı [MEB], 2013). 
Böylece teknoloji kültürünü toplumda yerleştirebilmek ve teknolojiyi anlayabilen, uygulayabilen ve tasarlayabilen birey yetiştirmede fen bilimleri dersi daha erken yaş ve seviyede okutularak, bu dersin önemli bir yere sahip olduğu vurgulanmıştır.

Fen bilimleri dersinin etkili işlenmesinde ders içerisinde kullanılan araç-gereçler ve ders kitaplarının yeterliliği önem arz etmektedir (Kılıç, 2001). Ders kitapları Milli Eğitim Bakanlığı'na bağlı Talim ve Terbiye Kurulu Başkanlığı (TTKB) tarafından oluşturulan öğretim programları çerçevesinde hazırlanmaktadır. Ders kitaplarının içeriği ile öğretim programlarının içeriği birbirinden bağımsız olmamalıdır. Böylece eğitimdeki hedeflerle ders materyali arasında bir uyum sağlanmış olur (Ceyhan ve Yiğit, 2005). illkokul fen bilimleri dersi öğretim programına bakıldığında programının vizyonu; "Tüm öğrencileri fen okuryazarı bireyler olarak yetiştirmek" olarak tanımlanmıştır. Ayrıca programın amaçlarından biride "Bilimin toplumu ve teknolojiyi, toplum ve teknolojinin de bilimi nasıl etkilediğine ilişkin farkındalık geliştirmek" olarak belirtilmiştir (MEB, 2013). İlkokul fen bilimleri dersi programı incelendiğinde fen okuryazarlığının Fen-Teknoloji-Toplum-Çevre(FTTÇ) öğrenme alanının kapsamında olduğu görülmektedir. Yager (1996), FTTÇ eğitiminin temel amacını bir toplumun tüm bireylerinin bilimsel ve teknolojik okuryazarlığını arttırmak olarak tanımlamıştır. Ayrıca programda FTTÇ öğrenme alanı kapsamında şu alt alanlar yer almaktadır:

(a) Sosyo-Bilimsel Konular: Bilim ve teknoloji ile ilgili sosyo-bilimsel problemlerin çözümüne yönelik bilimsel ve ahlaki muhakeme becerilerini kapsamaktadır. (b) Bilimin Doğası: Bilimin ne olduğu, bilimsel bilginin nasıl ve ne amaçla oluşturulduğu, bilginin geçtiği süreçleri, bilginin zamanla değişebileceğini ve bilginin yeni araştırmalarda nasıl kullanıldığını anlamayı kapsamaktadır. (c) Bilim ve Teknoloji illişkisi: Bilim ve teknolojinin karşııklı etkileşimi ve birbirlerine olan katkısına yönelik anlayışı kapsamaktadır. (ç) Bilimin Toplumsal Katkısı: Bilimsel bilginin toplumsal gelişime ve toplumsal sorunların çözümüne olan katkısını anlamayı kapsamaktadır. (d) Sürdürülebilir Kalkınma: Doğal kaynakların tasarruflu kullanılarak gelecek nesillerin intiyaçlarının karşılanmasına olanak tanınması, tasarruflu kullanımın bireysel, toplumsal ve ekonomik faydalarına ilişkin bilinç geliştirmeyi kapsamaktadır. (e) Fen ve Kariyer Bilinci: Fen Bilimleri alanındaki mesleklerin farkında olma ve bu mesleklerin bilimsel bilginin gelişimine yaptığı katkıya ilişkin bilinç geliştirmeyi kapsamaktadır.

Ancak üçüncü ve dördüncü sınıf fen bilimleri dersi öğretim programı kazanımları incelendiğinde yukarıda bahsedilen alanlara neredeyse hiç yer verilmediği, üçüncü ve dördüncü sınıf fen bilimleri dersi öğretim programının giriş açıklamasında "bilgi, beceri ve duyuş sahibi olmaları beklenmektedir." ifadesinin yer aldığı görülmektedir. Bu bağlamda üçüncü ve dördüncü sınıf fen bilimleri dersi ders kitapları incelenmiş, programın genel vizyon ve amaçlarına uymadığı, kitapta yer alan konuların sadece "bilgi" basamağında kaldığı ve yukarda sözü edilen FTTÇ öğrenme alanına ve alt alanlarına neredeyse hiç yer verilmediği görülmüştür (MEB, 2013). Fen okuryazarı bireyler yetişmesinde bir diğer önemli etkende sınıf ortamlarında teknoloji uygulamaları ve tasarımlarıdır. Fen Bilimleri dersinde yakın çevreden edinilen çeşitli öğretim materyallerinin (maket, model, vb.) ve teknolojinin kullanılması öğrencilerin öğrendikleri bilgilerin günlük hayatla ilişki kurmasında yardımcı olmasının yanı sıra teknolojiyi öğrenme imkânı da sağlayacaktır. Öğrencilerin fen bilimleri derslerine var olan ilgi ve merakları, teknolojinin çok yönlü kullanımı ile daha da artacak böylece keşfetme ve bir ürün ortaya çıkarmaya yönelik olumlu tutum sergileyeceklerdir. Böylece öğrencinin bilgiye ezberleyerek değil, araştırarak, keşfederek ve bunları yorumlayarak ulaşması sağlanacaktır (Akpınar, Aktamış ve Ergin, 2005; Özmen, 2004; Ültay ve Çalık, 2016). Üçüncü ve dördüncü sınıf fen bilimleri dersi ders kitapları incelenmiş ve fen bilimleri dersi öğretim programıyla uyuşmazlıklar dikkate alındığında ders kitaplarının teknoloji uygulamaları ve teknoloji tasarımları yönünden yetersiz kaldığı düşünülmektedir. Literatür incelendiğinde 2005 'te yenilenen öğretim programı 
doğrultusunda hazırlanmış ders kitaplarına yönelik 2005-2011 yılları arasında yayınlanan çalışmalar ve lisansüstü tezler bulunmaktadır (Ayvacı ve Er Nas, 2009; Ayvacı ve Şenel Çoruhlu, 2011; Bağdatlı,2005; Erdoğan, 2007; Gömleksiz ve Bulut,2007; Güneş, Çelikler ve Gökalp, 2008; İpek, Sağlam ve Duysak,2007; Laçin Şimşek, 2009; Laçin Şimşek, 2010; Ocak, 2008; Şahin,2008; Tekbıyık ve Akdeniz, 2008; Topal, 2009; Tüysüz ve Aydın, 2009; Yeşilaydın,2008; Yılmaz,2010). Ayrıca 2013 Fen Bilimleri dersi öğretim programı ile 2005 Fen ve Teknoloji dersi öğretim programının karşılaştırıımasına yönelik üç çalışmaya (Eskicumalı, Demirtaş, Gür Erdoğan ve Arslan, 2014; Karatay, Timur ve Timur, 2013; Saban, Aydoğdu ve Elmas, 2014) ve 2013 fen bilimleri dersi öğretim programına ilişkin öğretmen görüşlerinin alınıp değerlendirildiği iki çalışmaya (Ayvacı ve Özbek, 2014; Toraman ve Alcı, 2013) rastlanmıştır. Ancak, 2013 fen bilimleri dersi öğretim programı ile fen bilimleri dersi ders kitaplarındaki teknoloji uygulamaları ve tasarımlarına yönelik herhangi bir çalışmaya rastlanmamıştır.

Öğretmenlerin, fen bilimleri derslerindeki teknoloji uygulama veya tasarım çalışmaları, öğrencilerin fen bilimlerine olan tutumlarını da olumlu yönde etkilemektedir (Akpınar ve vd., 2005; Gümüş, Demir, Koçak, Kaya ve Kırıcı, 2008). Fen Bilimleri derslerindeki teknoloji uygulamaları ve tasarımlarının yürütücüleri olan öğretmenlerinde, öğrencilerin fen bilimlerine karşı olumlu tutum sergilemelerinde önemli bir yeri vardır (Arslan ve Özpınar, 2008). Ayrıca öğretmenler eğitim ve öğretimin belirlenen amaçlar doğrultusunda gerçekleştirilmesinde ve başarıya ulaşmasında önemli rol oynamaktadırlar (Bakar, Keleş ve Koçakoğlu, 2009). Huinker ve Madison (1997), fen bilgisi eğitimi alanındaki bir çalışmalarında, öğretmenlerin fen bilgisine ve fen bilgisi öğretimine karşı tutumlarının onların fen bilgisi öğretimine yönelik davranışlarını etkilediğini belirtmiştir. Eğitim sisteminde süreci düzenleyen ve yönlendiren referans kişi olarak, öğretmen niteliği önemlidir. Öğrencileri yetiştiren öğretmenler olduğuna göre onlara yön veren öğretmenlerin çağdaş, nitelikli ve teknolojik gelişmelere hâkim olması gerekir (Kenar, 2013). Bu anlamda program ve ders kitaplarının uygulayıcısı olan öğretmenlerin bu alanda nitelikli olmaları gerekmektedir. Bu sebeple yeni olan 2013 fen bilimleri dersi öğretim programının uygulanma aşaması çok önemlidir. Çünkü bir programın başarılı ya da başarısız olması nasıl uygulandığına bağlıdır (Tüysüz ve Aydın, 2009).

Bu bağlamda fen bilimleri dersi öğretim programının ve ders kitaplarının yeni olmasından dolayı literatürde de bu alanda boşluk bulunması sebebiyle program ve ders uygulayıcısı olan öğretmenlerin, teknoloji okuryazarı bireyler yetiştirmek için, teknoloji uygulamaları ve tasarımları hakkındaki görüşlerinin alınması gerekli görülmektedir. Bu gerekçelerle de bu çalışmada araştırılan problem, "Sınıf öğretmenlerinin teknoloji uygulamaları ve tasarımına ilişkin görüşleri nelerdir?" şeklindedir.

\section{YÖNTEM}

Bu çalışma nitel bir çalışma olup, araştırma yaklaşımlarından yorumlayıcı yaklaşımın bir yöntemi olan özel durum çalışması yöntemi kullanıımıştır. Yorumlayıcı yaklaşım bir durumun arkasındaki nedenleri derinlemesine elde etmektir (Çepni, 2005). Özel durum çalışması yöntemi ise güncel bir olgu, olay, durum, birey ve gruplar üzerine odaklanılıp derinlemesine incelemeye çalışılmasıdır ve mevcut durum nedir sorusuna cevap arar (Bassey, Stake ve Yin'den Aktaran Ekiz, 2009).

\section{1. Çalışma grubu}

Bu bağlamda bu çalışmanın evrenini sınıf öğretmenleri oluşturmakta olup örneklem olarak Doğu Karadeniz bölgesindeki bir devlet okulunda görev yapan ve 4. sınıfları okutan 12 sınıf öğretmeni seçilmiştir. Örnekleme yöntemi olarak, seçkisiz örnekleme yöntemlerinden, basit seçkisiz yöntem kullanılmış ve gönüllü katılımcılarla çalışımıştır. Katılımcıların demografik bilgileri Tablo 1'de sunulmuştur. 
Tablo 1.

Mülakata Katılan Öğretmenlerin Demografik Bilgileri

\begin{tabular}{|c|c|c|c|c|c|c|}
\hline Kod & Cinsiyet & Yaş & $\begin{array}{l}\text { Hizmet } \\
\text { Yılı }\end{array}$ & Öğrenim Durumu & $\begin{array}{l}\text { Mezun Olunan } \\
\text { Bölüm }\end{array}$ & $\begin{array}{l}\text { Mezun Olunan } \\
\text { Üniversite }\end{array}$ \\
\hline Ö1 & Erkek & 49 & 30 & $\begin{array}{l}\text { Ön Lisans (Lisans } \\
\text { Tamamlama) }\end{array}$ & $\begin{array}{l}\text { Sınıf } \\
\text { Öğretmenliği }\end{array}$ & $\begin{array}{l}\text { Giresun Eğitim } \\
\text { Enstitüsü }\end{array}$ \\
\hline Ö2 & Erkek & 60 & 27 & Ön Lisans & $\begin{array}{l}\text { Sınıf } \\
\text { Öğretmenliği }\end{array}$ & $\begin{array}{l}\text { Giresun Eğitim } \\
\text { Enstitüsü }\end{array}$ \\
\hline 0̈3 & Bayan & 60 & 38 & Ön Lisans & $\begin{array}{l}\text { Sınıf } \\
\text { Öğretmenliği }\end{array}$ & $\begin{array}{l}\text { Giresun Eğitim } \\
\text { Enstitüsü }\end{array}$ \\
\hline Ö4 & Erkek & 57 & 36 & Ön Lisans & $\begin{array}{l}\text { Sınıf } \\
\text { Öğretmenliği }\end{array}$ & $\begin{array}{l}\text { Tekirdağ Eğitim } \\
\text { Enstitüsü }\end{array}$ \\
\hline Ö5 & Bayan & 45 & 26 & Ön Lisans & $\begin{array}{l}\text { Sınıf } \\
\text { Öğretmenliği }\end{array}$ & $\begin{array}{l}\text { Giresun Eğitim } \\
\text { Enstitüsü }\end{array}$ \\
\hline Ö6 & Bayan & 58 & 37 & Ön Lisans & $\begin{array}{l}\text { Sınıf } \\
\text { Öğretmenliği }\end{array}$ & $\begin{array}{l}\text { Giresun Eğitim } \\
\text { Enstitüsü }\end{array}$ \\
\hline Ö7 & Bayan & 31 & 8 & Lisans & $\begin{array}{l}\text { Sınıf } \\
\text { Öğretmenliği }\end{array}$ & $\begin{array}{l}\text { Afyon Kocatepe } \\
\text { Üniversitesi }\end{array}$ \\
\hline Ö8 & Bayan & 47 & 25 & $\begin{array}{l}\text { Ön Lisans (Lisans } \\
\text { Tamamlama) }\end{array}$ & $\begin{array}{l}\text { Sınıf } \\
\text { Öğretmenliği }\end{array}$ & $\begin{array}{l}\text { Giresun Eğitim } \\
\text { Enstitüsü }\end{array}$ \\
\hline Ö9 & Bayan & 53 & 30 & Lisans & $\begin{array}{l}\text { Sınıf } \\
\text { Öğretmenliği }\end{array}$ & $\begin{array}{l}\text { Trakya Eğitim } \\
\text { Enstitüsü }\end{array}$ \\
\hline Ö10 & Erkek & 44 & 21 & Yüksek Lisans & $\begin{array}{l}\text { Kimya } \\
\text { Öğretmenliği }\end{array}$ & $\begin{array}{l}\text { Karadeniz Teknik } \\
\text { Üniversitesi }\end{array}$ \\
\hline Ö11 & Bayan & 45 & 19 & Lisans & İşletme & $\begin{array}{l}\text { Karadeniz Teknik } \\
\text { Üniversitesi }\end{array}$ \\
\hline Ö12 & Erkek & 55 & 37 & Ön Lisans & $\begin{array}{l}\text { Sınıf } \\
\text { Öğretmenliği }\end{array}$ & $\begin{array}{l}\text { Gümüşhane Eğitim } \\
\text { Enstitüsü }\end{array}$ \\
\hline
\end{tabular}

Tablo 1'de demografik bilgileri verilen öğretmenlerin 7'si bayan 5'i erkektir. Hizmet yılı en az olan 8 en fazla olan ise $37^{\prime}$ dir. Katılımcıların yaşları 31-60 arasındadır. Öğretmenlerin $10^{\prime} u$ sınıf öğretmenliği, 1'i kimya öğretmenliği, $1^{\prime} i$ işletme mezunudur. Katılımcıların öğrenim durumları incelendiğinde,6'sının ön lisans, 2'sinin ön lisans + lisans tamamlama, 3'ünün lisans ve $1^{\prime}$ inin de yüksek lisans mezunu olduğu görülmektedir. Mezun oldukları okullara bakıldığında ise, öğretmenlerin 9'unun eğitim enstitülerinden, 3'ününde üniversitelerden mezun olduğu Tablo 1'de sergilenmektedir.

\subsection{Veri toplama süreci ve veri analizi}

Çalışmada, veri toplama amacıyla yarı yapılandırılmış mülakat tekniği kullanılmıştır. Yarı yapılandırılmış mülakat tekniğinde araştırmacı soruları önceden hazırlar ancak mülakat sırasında mülakat sorularında esneklik söz konusudur (Ekiz, 2009). Çalışmanın katılımcıları ile yürütülen mülakatlar yüz yüze gerçekleştirilmiş olup, her bir katılımcı için ortalama 20-25 dakika kadar sürmüştür. Veri toplamak amacıyla hazırlanan mülakat soruları 9 temel sorudan oluşmaktadır. Ses kayıt cihazı ile elde edilen mülakat verileri transkript edilmiş olup, veriler betimsel-yorumsal analize tabi tutulmuş ve bulgular kısmında sunulmuştur.

\subsection{Araştırmada Nitelik}

Veri toplama süreci başlamadan önce araştırmacı tarafından geliştirilen mülakat sorularının görünüş ve kapsam geçerliğinin sağlanması için bir alan eğitimi uzmanına ve anlaşılırlık açısından da bir Türkçe dil uzmanına kontrol ettirilmiş olup, uzmanların görüşleri doğrultusunda gerekli düzenlemeler yapılmıştır. 
Veri toplama süreci başlamadan önce katılımcılara, araştırmacı tarafından "verilerin sadece araştırma amaçı kullanılacağı" ve "bazı demografik bilgileriniz dışında hiçbir verinin çalışmanın okurları ile paylaşılmayacă̆ı" gibi bilgiler sunulmuştur. Bu bilgilendirmenin amacı, katılımcıların veri toplama sürecinde rahat ve içten cevap vermelerini sağlayıp çalışmanın inandırıcılığını artırmaktır.

Ayrıca veri toplama süreci katılımcıların alışık olduğu ortamda yani kendi iş yerlerinde gerçekleştirilerek çalışmanın inandırıcılığı artırılmaya çalışılmıştır. Veri toplama aşamasında, yaklaşık 20-25'er dakika süren ve yüz yüze gerçekleştirilmiş olan mülakatların ses kayıt cihazı ile yapılan ses kayıtları katılımcıların izni alınarak gerçekleştirilmiştir.

Katılımcılar tarafından mülakattaki sorulara verilen cevaplar, çalışmanın inandırıcılık ve tutarlılığını artırmak amacıyla, farklı zaman ve mekânlarda üç defa gerekli indirgemeler yapılıp kritik cevaplar tespit edilerek betimlenmeye çalışımıştır. Bu aşamaların geçerlik ve güvenirliği uzman görüşleri ile sağlanmıştır. Ayrıca mülakatlardan elde edilen ham veriler işlenerek gerekli indirgemeler yapıldıktan sonra her bir katılımcıya kontrol ettirilerek onayları alınmış, ekleme veya çıkarma yapmak istedikleri bir nokta olup olmadığı sorulmuş, katılımcı kontrolü sağlanmıştır.

Aktarılabilirlik, nitel araştırmalarda genelleme yerine kullanılan bir diğer kriterdir (Miles ve Huberman, 1994). Nitel araştırmalarda araştırma sonuçlarının genellemesinden ziyade benzer durumlara aktarılabilirliği söz konusudur (Yıldırım ve Şimşek, 2011). Bu çalışmada aktarılabilirliğin arttırılması adına araştırma sürecinde elde edilen veriler bulgular bölümünde okuyucuya yorum yapılmadan ve verilerin doğasına bağlı kalınarak sunulmuştur. Bu şekilde okuyucu araştırılan duruma ilişkin sonuçlara daha net bir şekilde ulaşacak ve kendi oluşturduğu araştırma durumlarına aktarma fırsatını elde edecektir. Ayrıca, araştırmacının elde ettiği sonuçların veri tarafından desteklenmesi gerekmektedir (Miles ve Huberman, 1994). Bu, teyit edilebilirliğin göstergesidir. Bu araştırmada da katılımcıların doğrudan ifadelerine yer verilerek teyit edilebilirlik sağlanmaya çalışılmıştır.

\subsection{Araştırmada Etik}

Araştırmaya dâhil edilen katılımcıların, veri toplama sürecinde toplanan verilerinin okuyucu ile paylaşımı konusunda rızaları alınmıştır. Ayrıca çalışmanın katılımcıları olan öğretmenlerin bazı demografik bilgilerinin de okuyucu ile paylaşılacağı açıkça belirtilerek onayları alınmış araştırmadan herhangi bir şekilde zarar görmeyecekleri belirtilmiştir (Cohen ve Manion, 1989; Drew, Hardman ve Hart, 1996). Veri toplama sürecinde araştırmacı ile katılımcılar arasında geçen bazı özel diyaloglar mahremiyet ve gizlilik ilkelerince araştırmaya yansıtılmamıştır. Bununla birlikte, araştırma etiği çerçevesinde, veri toplama sürecine katılan öğretmenler sırası ile Ö1, Ö2, Ö3, ..., Ö12 şeklinde kodlanarak isim gizliliği sağlanmıştır.

\section{BULGULAR}

Bu bölümde, Milli Eğitim Bakanlığı'nda (MEB) çalışan ve ilkokul 4. sınıfları okutan 12 sınıf öğretmeniyle yarı yapılandırılmış mülakatlar yoluyla elde edilen veriler, indirgemeler yapıldıktan sonra tablolar halinde sunulmuştur. Ayrıca, bazı örnek ifadeler, öğretmenlerin kodları kullanılarak, yorum yapılmadan olduğu gibi verilmiştir.

Öğretmenlerin fen bilimleri dersi öğretim programı hakkındaki bilgilerini tespit etmek amacıyla Soru 1 yöneltilmiş ve elde edilen veriler Tablo 2'de sunulmuştur. 
Tablo 2.

Öğretmenlerin "Soru 1"e Verdiği Cevaplar

Soru 1)Fen Bilimleri dersi öğretim programı hakkında yeterli bilgiye sahip olduğunuzu düşünüyor musunuz? Fen Bilimleri dersi öğretim programı ne tür bilgiler içerir? Bilgi verir misiniz?

\begin{tabular}{lccc}
$\begin{array}{l}\text { bilgiye sahip olduğunuzu düşünüyor musunuz? Fen Bilimleri } \\
\text { dersi öğretim programı ne tür bilgiler içerir? Bilgi verir misiniz? }\end{array}$ & ö & $\mathbf{f}$ & $\%$ \\
\hline $\begin{array}{l}\text { Evet, yeterli bilgiye sahibim. Öğrenme alanları, misyonu, } \\
\text { vizyonu, temel amaçları hakında bilgim var. }\end{array}$ & Ö5,Ö8,Ö9,Ö11 & 4 & 33.34 \\
$\begin{array}{l}\text { Biraz bilgim var. } \\
\text { Evet, bilgim var (öğretmen yanlış bilgiler sunar). }\end{array}$ & Ö10,Ö12 & 2 & 16.66 \\
Hayır, bilgim yok. & Ö2,Ö4,Ö6 & 4 & 33.34 \\
\hline
\end{tabular}

Tablo 2'de öğretmenlerin "Fen Bilimleri dersi öğretim programı hakkında yeterli bilgiye sahip olduğunuzu düşünüyor musunuz? Fen Bilimleri dersi öğretim programı ne tür bilgiler içerir? Bilgi verir misiniz?" sorusuna verdikleri cevaplar görülmektedir. Örneğin program hakkında bilgisi olduğunu söyleyen \%66.68'lik (\%33.34 + \%33.34) kısımdan (toplam 8 öğretmen), Ö8 kodlu öğretmen düşüncelerini "Evet yeterli bilgiye sahip olduğumu düşünüyorum. Programda kazanımlar var üniteler hakkında bilgiler var. Öğrencinin yaşadığı tabiatı, evreni, dünyamızı, enerjileri tanımasını sağlamaya, hissettirmeye, çevresini yorumlamasını sağlamaya yönelik bilgiler var." şeklinde ifade ederken; aynı yüzdelik dilimde bulunmasına rağmen fen bilimleri dersi öğretim programının içeriği ile ilgili yanlış açıklamalar yapan Ö1 kodlu öğretmen görüşünü "Programa baktım, var olan kaynakları inceledim. Program hakkında içerik olarak genel bir görüşüm var. Direkt çocuğun yaşantısıyla ilgili, ağırıklı olan konular var. Okullarda bu dersi işlemek için materyal yok, ilkokullarda laboratuvar yok. Fen Bilimleri dersi için sadece projeksiyon, bilgisayar gibi cihazlardan, morpa gibi programlardan yararlanıyoruz. Okullar bu konuda yetersiz düzenleme yapılması gerekiyor." ifadelerini kullanarak açıklamıştır.

Öğretmenlerin fen bilimleri dersi öğretim programında yer alan öğrenme alanlarına yönelik bilgilerini yoklamak amacıyla Soru 2 sorulmuş ve veriler Tablo 3'te sunulmuştur.

Tablo 3.

Öğretmenlerin "Soru 2"ye Verdiği Cevaplar

\begin{tabular}{lccc}
\hline $\begin{array}{l}\text { Soru 2) Fen Bilimleri dersi öğretim programında yer alan } \\
\text { ögrenme alanları nelerdir? Kısaca bilgi verir misiniz? }\end{array}$ & ö & $\mathrm{f}$ & $\%$ \\
\hline Bilmiyorum. & $\begin{array}{c}\text { Ö1,Ö2,ö5,Ö6,Ö9, } \\
\text { Ö10,Ö11,Ö12 }\end{array}$ & 8 & 66.67 \\
& Ö3,Ö4,Ö7,0̈8 & 4 & 33.33 \\
\hline
\end{tabular}

Tablo 3'te öğretmenlerin "Fen Bilimleri dersi öğretim programında yer alan öğrenme alanları nelerdir? Kısaca bilgi verir misiniz?” sorusuna verdikleri cevaplar görülmektedir. Öğretmenlerin büyük çoğunluğunun öğrenme alanlarına ilişkin bilgiye (Bilgi, Beceri, Duyuş ve FTTÇ) sahip olmadıkları görülmektedir. Bu soruya öğretmenlerin \%66.67'si "Bilmiyorum" 
cevabını verirken \%33.33'ü programda yeri gösterildikten sonra içerik olarak bildiklerini ancak başlık olarak bilmediklerini ifade etmiştir. Örneğin Ö8 kodlu öğretmen görüşlerini "Bu başlıları çok önemsemiyoruz, bu açıklanan şeyleri derslerimizde işliyoruz zaten. Bu biliş düzeyine onları ulaştırıyoruz. Bana derseniz ki beceri düzeyinin başlıkları neler, ben onları ezberimden size söyleyemem ama uyguladığımız şeyler bunlar zaten." şeklinde ifade etmiştir.

Öğretmenlerin fen bilimleri dersi öğretim programı ile ders kitaplarının uyumluluğu hakkındaki görüşlerini belirlemek amacıyla Soru 3 yöneltilmiş ve veriler Tablo 4'te sunulmuştur.

Tablo 4.

Öğretmenlerin "Soru 3"e Verdiği Cevaplar

\begin{tabular}{|c|c|c|c|}
\hline $\begin{array}{l}\text { Soru 3) Sizce fen bilimleri dersi öğretim programı ile ders } \\
\text { kitapları uyuşuyor mu? Uyuşan ve/veya uyuşmayan } \\
\text { noktaları nelerdir? }\end{array}$ & ö & $f$ & $\%$ \\
\hline Evet uyuşuyor. & Ö8,Ö11 & 2 & 16.66 \\
\hline Hayır uyuşmuyor. & Ö1,Ö3,Ö4,Ö5, Ö10 & 5 & 41.67 \\
\hline $\begin{array}{l}\text { Evet, uyuşuyor (öğretmen örnek vermez/çelişkili cevap } \\
\text { verir). }\end{array}$ & Ö2,ö6,Ö7,Ö9,ö12 & 5 & 41.67 \\
\hline
\end{tabular}

Tablo 4'te öğretmenlerin "Sizce Fen Bilimleri dersi öğretim programı ile ders kitapları uyuşuyor mu? Uyuşan ve/veya uyuşmayan noktaları nelerdir?" sorusuna verdikleri cevaplar görülmektedir. Bu cevaplara göre, Ö8 kodlu öğretmen düşüncesini "Uyuştuğunu düşünüyorum. Yılık programımıza, zaman çizelgemize baktığımda konu başlıklarının eş zamanlı gittiğini görüyorum." şeklinde ve Ö11 kodlu öğretmen de benzer şekilde düşüncesini "Uyuştuğunu düşünüyorum. Kazanımlarla etkinlikler uyuşuyor" şeklinde dile getirmiştir. Ancak Ö4 kodlu öğretmen aynı soruya "Uyuşup uyuşmama değil de kitap yüzeysel kalıyor. Mesela programda analitik düşünme becerisini geliştirme diyor ama kitapta çok az yer ayrılmış bu duruma." şeklinde cevap vermiştir. Ö6 kodlu öğretmen ise düşüncelerini "Uyuşuyor ama kitabın daha zengin bilgilerle donatılmış, çocuğun seviyesine uygun olmasını isterdim. Kitapta konular çok dağınık, dolayısıyla yardımcı kitap kullanıyoruz. Ders kitabı, görseller ve bilgi yönünden zayıf kalıyor. Kitaba kalsak ulaşacağımız bilgi ve amaca ulaşmamız zor olur." şeklinde ifade etmiştir.

Öğretmenlerin, fen bilimleri dersi ders kitaplarında, teknoloji tasarım veya teknoloji uygulama etkinliklerine yeterince yer verilip verilmediği hakkındaki görüşlerini belirlemek amacıyla Soru 4 yöneltilmiş ve veriler Tablo 5'te sunulmuştur.

\section{Tablo 5.}

Öğretmenlerin "Soru 4"e Verdiği Cevaplar

Soru 4) Fen-Teknoloji-Toplum-Çevre Öğrenme Alanı

kapsamında, fen bilimleri dersi ders kitaplarında teknoloji

tasarım veya teknoloji uygulama etkinliklerine yeterince

ö $\quad$ f $\%$

yer verildiğini düşünüyor musunuz? 
Tablo 5'te öğretmenlerin “Fen-Teknoloji-Toplum-Çevre öğrenme alanı kapsamında, Fen Bilimleri dersi ders kitaplarında teknoloji tasarımı veya teknoloji uygulama etkinliklerine yeterince yer verildiğini düşünüyor musunuz?" sorusuna verdikleri cevaplar sergilenmiştir. Öğretmenlerin tamamı, fen bilimleri dersi ders kitabında, teknoloji tasarım veya teknoloji uygulama etkinliklerinin yeterli miktarda olmadığı konusunda hemfikirdir.

Soru 4'ün opsiyonel sorusu olan "Sizce bu tür etkinlikler gerekli midir? Neden?" sorusuna yönelik öğretmenlerin görüşleri Tablo 5.a'da sunulmuştur.

Tablo 5.a.

Öğretmenlerin "Soru 4"ün Opsiyonel Sorusuna Verdiği Cevaplar

\begin{tabular}{lccc}
\hline Sizce bu tür etkinlikler gerekli midir? Neden? & Ö & $\mathrm{f}$ & $\%$ \\
\hline $\begin{array}{l}\text { Yaparak yaşayarak öğrenmenin gerçekleşmesi için } \\
\text { gereklidir. }\end{array}$ & Ö4,0̈7,0̈6,Ö9 & 4 & 33.34 \\
$\begin{array}{l}\text { Uzamsal düşünebilme ve farklı zekâ alanlarını ortaya } \\
\text { koymak için gereklidir. }\end{array}$ & Ö8 & 1 & 8.33 \\
$\begin{array}{l}\text { O alanda derinlemesine gitmek isteyen çocuklara alt } \\
\text { yapı oluşturmak için gereklidir. }\end{array}$ & Ö11 & 1 & 8.33 \\
\begin{tabular}{l} 
Gereklidir (öğretmen nedenini açıklamaz). \\
\hline
\end{tabular} & Ö1,Ö2,Ö3,Ö5,Ö10,Ö12 & 6 & 50.00 \\
\hline
\end{tabular}

Tablo 5.a incelendiğinde, öğretmenlerin tamamı teknoloji tasarım ve uygulama etkinliklerinin gerekli olduğunu düşünmektedir. Ayrıca aynı tabloda öğretmenlerin, bu tür etkinliklerin neden gerekli olduğu hakkındaki görüşleri de sunulmuştur. Mesela, Ö4 kodlu öğretmen görüşlerini "Ben stetoskobu üniversiteyi bitirince birebir gördüm doktor arkadaşlarım vasıtasıyla. Bu etkinliklerle çocuk görüyor öğreniyor. Bizim zamanımızda böyle şeyler yoktu." şeklinde ifade ederken, öğretmenlerin \%50'si bu tür etkinliklerin neden gerekli olduğuna dair açıklama yapmamışlardır.

Öğretmenlerin teknoloji tasarımlarına yönelik ödev/proje verip vermeme durumlarını belirlemek amacıyla Soru 5 yöneltilmiş, bu soru ve alt sorularına yönelik bulgular sırasıyla tablolaştırılarak sunulmuştur.

Tablo 6.

Öğretmenlerin "Soru 5"e Verdiği Cevaplar

\begin{tabular}{lccc}
\hline $\begin{array}{l}\text { Soru 5) Teknoloji tasarımlarına yönelik öğrencilere } \\
\text { ödev/proje veriyor musunuz? }\end{array}$ & ö & $\mathrm{f}$ & $\%$ \\
\hline Evet, veriyorum. & $\begin{array}{l}\text { Ö1,Ö2,Ö3,Ö4, } \\
\text { Ö5,Ö6,Ö8,Ö9 }\end{array}$ & 8 & 66.66 \\
Hayır, vermiyorum. & Ö7,Ö10,Ö11,Ö12 & 4 & 33.34 \\
\hline
\end{tabular}

Tablo 6'ya bakıldığında öğretmenlerin \%66.66'sının teknoloji tasarımlarına yönelik ödev/proje verdikleri görülmektedir. Ödev/proje veren öğretmenlerin alt sorulara verdikleri cevaplar aşağıdaki tablolarda (Tablo 6.1.a-b-c) sunulmuştur.

Tablo 6.1.a.

Öğretmenlerin "Soru 5"in Alt Sorusuna Verdiği Cevaplar

\begin{tabular}{lccc}
\hline Ne tür ödev/proje veriyorsunuz? & Ö & f & $\%$ \\
\hline Araştırma ödevi veriyorum. & Ö1,Ö2,Ö3,Ö4, Ö5,Ö6,Ö8,Ö9 & 8 & 100 \\
\hline
\end{tabular}


Tablo 6.1.a'da, mülakatın 5. sorusunun 1.alt sorusu olan "Ne tür ödev/proje veriyorsunuz?" sorusuna, ödev/proje veren öğretmenlerin tamamı, araştırma ödevi verdiklerini belirtmişlerdir. Örneğin, Ö3 kodlu öğretmen düşüncelerini "Teorik ödevler veriyorum. Çocuktan bir bilim adamının yerine geçmesini istiyorum. Onun buluşlarını, hayatını, hayat şartıarını araştır diyorum. Böyle imkânların olsa sen neler yapardın gibi yönlendirmeler yapıyorum." şeklinde ifade ederken, Ö5 kodlu öğretmen "Bir televizyonun sana gelişine kadar geçtiği üretim süreci aşamaları hakkında bilgiler topla gibi ödevler veriyorum.", Ö8 kodlu öğretmen de "Mesela röntgeni araştırma ödevi olarak vermiştim." şeklinde düşüncelerini dile getirmişlerdir.

Tablo 6.1.b.

Öğretmenlerin "Soru 5"in Alt Sorusuna Verdiği Cevaplar

\begin{tabular}{lccc}
\hline Bu ödevleri/projeleri ne amaçla veriyorsunuz? & ö & $\mathrm{f}$ & $\%$ \\
\hline Öğrenmenin gerçekleştirilmesi için. & Ö1,Ö2, Ö5,Ö6 & 4 & 50.00 \\
Öğrencinin derse olan ilgi ve olumlu tutumunun artırmak için. & Ö4, Ö8,Ö9 & 3 & 37.50 \\
$\begin{array}{l}\text { Daha çok çocuğun özel yeteneklerini belirlemek ve çocuğu } \\
\text { tanımak için. }\end{array}$ & Ö3 & 1 & 12.50 \\
\begin{tabular}{l} 
Çocuğun kendine ait bir ürünü ortaya koyması için. \\
\hline
\end{tabular} & Ö4 & 1 & 12.50 \\
\hline
\end{tabular}

Tablo 6.1.b'de "Bu ödevleri/projeleri ne amaçla veriyorsunuz?" sorusuna öğretmenlerin çeşitli cevaplar verdikleri görülmektedir. Mesela, Ö5 kodlu öğretmen "Çocuk araştırmayı öğrensin, merak etsin. Hazır bilgi almasın, kendi araştırsın ve öğrensin. Bulduğunu ve öğrendiğini arkadaşlarıyla paylaşsın. Biraz da çocuğun altyapısını oluşturmak için veriyorum." şeklinde görüşünü ifade ederken, Ö8 kodlu öğretmen aynı soruya "Öğrencilerin ilgisini ortaya çıkarmaya çalışıyorum. Umarım ki ilerde bilimsel düzeyde bir soru ortaya atabilir ve o soru üzerinde araştırmaya nereden başlayacağını bulabilir." şeklinde cevap vermiştir. Ö4 kodlu öğretmen ise bu soruda görüşlerini şu şekilde dile getirmiştir: "Esas amacımız, ne kadar basit olursa olsun, çocuk kendi yaptığı bir şeyi görmeli. Böylece derse olan ilgisi, alakası, bakışı değişiyor. Ben de bir şeyler yapabiliyorum diyor. Ayrıca, ben yeterli donanıma sahip olursam daha iyi olur. Bize fen öğretimine yönelik seminer yapsalar iyi olurdu. Önce kendimiz yapacağız sonra yapılabilirliğini konuşacağız."

Tablo 6.1.c.

Öğretmenlerin "Soru 5"in Alt Sorusuna Verdiği Cevaplar

\begin{tabular}{lccc}
\hline $\begin{array}{l}\text { Bu ödevlerde/projelerde sizin rolünüz nedir ve bu ödevleri/projeleri } \\
\text { dersin değerlendirilmesine dâhil ediyor musunuz? }\end{array}$ & ö & $\mathrm{f}$ & $\%$ \\
\hline Rehberim, dâhil ediyorum. & Ö1,Ö4 & 2 & 25.00 \\
Rehberim, dâhil etmiyorum. & Ö8 & 1 & 12.50 \\
Rehberim, performans davranışına yansıyor. & Ö2,Ö5 & 2 & 25.00 \\
Yönlendiriciyim, dâhil ediyorum. & Ö9 & 1 & 12.50 \\
Yönlendiriciyim dâhil etmiyorum. & Ö3 & 1 & 12.50 \\
Yönlendiriciyim, performans davranışına yansıyor. & Ö6 & 1 & 12.50 \\
\hline
\end{tabular}

Tablo 6.1.c'de öğretmenlerin "Bu ödevlerde/projelerde sizin rolünüz nedir ve bu ödevleri/projeleri dersin değerlendirilmesine dâhil ediyor musunuz?" sorusuna verdikleri cevaplar sunulmuştur. Ödev/proje veren öğretmenlerin çoğunluğu (\%62.50) bu ödevlerde/projelerde rehber durumunda olduklarını belirtmişlerdir. Örneğin bu soruya, rehber olduğunu ve ders değerlendirmesine dâhil etmediğini belirten Ö8 kodlu öğretmen "Her şeyi nota dönüştürmekten taraf değilim, not biraz tehdit gibi oluyor, daha çok eleştiri yapıyoruz." şeklinde düşüncelerini ifade ederken, Ö3 kodlu öğretmen bu soruya "Yönlendiriyorum, önce 
taslak hazırlıyoruz sonra kontrolümde eksiklerini tamamlıyoruz." şeklinde cevap vermiştir. Ayrıca Ö6 kodlu öğretmen düşüncesini "Sınıf içi performans notu olarak kullanıyorum, sorumluluğu yerine getirmiş mi getirmemiş mi diye." olarak ifade etmiştir.

Soru 6'da öğretmenlerin \%33.34'ü teknoloji tasarımlarına yönelik öğrencilere ödev/proje vermediğini belirtmişti. ilk olarak öğretmenlerin neden ödev/proje vermediklerine ilişkin cevapları Tablo6.2'desunulup daha sonra alt sorulara ilişkin cevapları tablolar halinde (Tablo 6.2.a-b-c) sunulmuştur.

Tablo 6.2.

Öğretmenlerin "Soru 5"in Alt Sorusuna Verdiği Cevaplar

\begin{tabular}{lccc}
\hline $\begin{array}{l}\text { Teknoloji tasarımlarına yönelik neden öğrencilere ödev/proje } \\
\text { vermiyorsunuz? }\end{array}$ & Ö & f & \% \\
\hline Program içeriğine göre hareket ettiğim için vermiyorum. & Ö7,Ö11 & 2 & 50.00 \\
Uygun konu olmadığı için vermiyorum. & Ö10 & 1 & 25.00 \\
Kitapta verilen bilgiler basit düzeyde ele alındığı için vermiyorum. & Ö12 & 1 & 25.00 \\
\hline
\end{tabular}

Tablo 6.2'de 5. soruya yönelik ödev/proje vermeyen öğretmenlere yöneltilmiş olan "Teknoloji tasarımlarına yönelik neden öğrencilere ödev/proje vermiyorsunuz?" sorusuna öğretmenlerin verdikleri cevaplar sunulmuştur. Ö7 ve Ö11 kodlu öğretmenler ders programı içeriğine göre hareket ettikleri için teknoloji tasarımına yönelik ödev/proje vermediklerini belirtirlerken, Ö10 kodlu öğretmen ders konularında bu tür ödev/proje verebilecekleri konuların olmadığını belirtmiştir.

Tablo 6.2.a.

Öğretmenlerin "Soru 5"in Alt Sorusuna Verdiği Cevaplar

\begin{tabular}{lccc}
\hline Eğer verseydiniz, ne tür ödev/proje verirdiniz? & Ö & $\mathbf{f}$ & \% \\
\hline Kendi ürünlerini ortaya koyabilecekleri ödevler verirdim. & Ö7 & 1 & 25.00 \\
Araştırarak öğrenecekleri ödevler verirdim. & Ö10 & 1 & 25.00 \\
Çocukların günlük yaşantılarına hitap eden ödevler verirdim. & Ö11 & 1 & 25.00 \\
Araştırma ve uygulama olarak iki tür ödev verirdim. & Ö12 & 1 & 25.00 \\
\hline
\end{tabular}

Tablo 6.2.a'da 5. soruya yönelik ödev/proje vermeyen öğretmenlerin "Eğer verseydiniz, ne tür ödev/proje verirdiniz?" sorusuna ilişkin verdikleri cevaplar gösterilmiştir. Öğretmenlerin verdikleri cevaplar çeşitlilik göstermiş ve tabloda aynen sunulmuştur.

Tablo 6.2.b.

Öğretmenlerin "Soru 5"in Alt Sorusuna Verdiği Cevaplar

\begin{tabular}{lccc}
\hline Eğer verseydiniz, bu ödevleri/projeleri ne amaçla verirdiniz? & ö & $\mathrm{f}$ & $\%$ \\
\hline Öğrencinin, konuyla ilgili kazanıma ulaşması için verirdim. & Ö11,Ö12 & 2 & 50.00 \\
Öğrencinin, özgüveninin gelişmesi için verirdim. & Ö7 & 1 & 25.00 \\
Öğrencinin, kendini geliştirmesi için verirdim. & Ö10 & 1 & 25.00 \\
\hline
\end{tabular}

Tablo 6.2.b'de 5. soruya yönelik ödev/proje vermeyen öğretmenlere yöneltilmiş olan "Eğer verseydiniz, bu ödevleri/projeleri ne amaçla verirdiniz?" alt sorusuna, öğretmenlerin verdikleri cevaplar sunulmaktadır. Teknoloji tasarımına yönelik ödev/proje vermeyen öğretmenlerin \%50'si, bu soruya “Öğrencilerin, konuyla ilgili kazanıma ulaşmaları için verirdim. Bu şekilde öğrenme gerçekleşirdi." cevabını vermişlerdir. 
Tablo 6.2.c.

Öğretmenlerin "Soru 5"in Alt Sorusuna Verdiği Cevaplar

Eğer verseydiniz, bu ödevlerde/projelerde sizin rolünüz ne olurdu ve bu ödevleri/projeleri dersin değerlendirilmesine dâhil eder miydiniz?

Rehber olurdum, dersin değerlendirmesine dâhil ederdim.

Ö7,Ö10,Ö11,Ö12 $4 \quad 100$

Tablo 6.2.c'de 5. soruya yönelik ödev/proje vermeyen öğretmenlere yöneltilmiş olan "Eğer verseydiniz, bu ödevlerde/projelerde sizin rolünüz ne olurdu ve bu ödevleri/projeleri dersin değerlendirilmesine dâhil eder miydiniz?" sorusuna, bütün öğretmenlerin "Rehber olurdum, dersin değerlendirmesine dâhil ederdim." cevabı verdikleri görülmektedir.

Öğretmenlerin teknoloji alanındaki gelişmeleri takip etmeleri/etmemeleri hakkında bilgi edinmek amacıyla öğretmenlere Soru 6 yöneltilmiş ve veriler Tablo 7'de sunulmuştur.

Tablo 7.

Öğretmenlerin "Soru 6"ya Verdiği Cevaplar

Soru 6) Teknoloji alanındaki gelişmeleri takip ediyor musunuz? Teknoloji alanındaki gelişmelerden, ders içerisinde, öğrencilerinize bahsediyor musunuz? Birkaç örnek verebilir misiniz?

Takip ediyorum. Ders içerisinde de bahsediyorum.

$$
\begin{gathered}
\text { Ö5,Ö6,Ö7,Ö8, } \\
\text { Ö9,Ö10,Ö11 }
\end{gathered}
$$

ö $\quad$ f $\quad \%$

$9,010,011$

Takip etmiyorum.

Ö1,Ö2,Ö3,Ö4,Ö12

$5 \quad 41.67$

Tablo 7'de öğretmenlerin “Teknoloji alanındaki gelişmeleri takip ediyor musunuz? Teknoloji alanındaki gelişmelerden, ders içerisinde, öğrencilerinize bahsediyor musunuz? Birkaç örnek verebilir misiniz?" sorusuna verdikleri cevaplar sunulmuştur. Bu tabloya göre öğretmenlerin \%41.67'si teknolojiyi takip etmediklerini belirtmişlerdir. Teknolojiyi takip ettiğini belirten öğretmenlerin (\%58.33) tamamı Soru 6'nın opsiyonel sorusuna Teknoloji alanındaki gelişmelerden ders içerisinde öğrencilere bahsettiklerini belirtmişlerdir. Bu soruya ilişkin örnek vermeleri istendiğinde, verdikleri örnekler; "ilk yerli otomobil", "Nobel ödülü almış olan Aziz Sancar", "solucan delikleri", "Mars'ta su bulunması" ve "Plüton'a ulaşılması" konuları olduğu belirlenmiştir.

Öğretmenlerin öğrenme ortamlarında hangi öğretim teknolojilerini kullandıklarını belirlemeye yönelik Soru 7 yöneltilmiş ve veriler Tablo 8'de sunulmuştur.

Tablo 8.

\begin{tabular}{|c|c|c|c|}
\hline $\begin{array}{l}\text { Soru 7) Fen Bilimleri dersi öğrenme ortamlarında (sınıf } \\
\text { ortamında) hangi öğretim teknolojilerini } \\
\text { kullanıyorsunuz? }\end{array}$ & ö & $f$ & $\%$ \\
\hline Bilgisayar ve projeksiyon & $\begin{array}{l}\text { Ö1,Ö2,Ö4,Ö5,Ö6,Ö7, } \\
\text { Ö8,Ö9,Ö10,Ö11,Ö12 }\end{array}$ & 11 & 91.66 \\
\hline Internet & Ö4,Ö7,Ö10,Ö11,Ö12 & 5 & 41.66 \\
\hline Bilişim teknolojileri & Ö6,Ö8 & 2 & 16.66 \\
\hline Vitamin ve morpa programları & Ö4 & 1 & 8.33 \\
\hline Kullanmıyorum. & 0̈3 & 1 & 8.33 \\
\hline
\end{tabular}

Öğretmenlerin "Soru 7"ye Verdiği Cevaplar 
Tablo 8'deki veriler, öğretmenlere yöneltilmiş olan "Fen Bilimleri dersi öğrenme ortamlarında (sınıf ortamında) hangi öğretim teknolojilerini kullanıyorsunuz?" sorusuna verdikleri cevapları içermektedir. Tablo 8'e göre, öğretmenlerin ağırlıklı olarak sınıf ortamlarında bilgisayar ve projeksiyonu kullandıkları görülmektedir. Sınıf ortamında öğretim teknolojisi kullanmayan Ö3 kodlu öğretmen, düşüncelerini "Kullanmıyorum. Çünkü çocuk evde yeterince izliyor ve bu cihazlara doyuyor. Artık ilgisini çekmiyor." şeklinde ifade etmiştir.

Soru 8'in opsiyonel sorusuna ilişkin veriler Tablo 8.1'de verilmiştir.

Tablo 8.1.

Öğretmenlerin "Soru 7"in Opsiyonel Sorusuna Verdiği Cevaplar

\begin{tabular}{lccc}
\hline $\begin{array}{l}\text { Bu teknolojileri dersin hangi aşamasında } \\
\text { (başında/ortasında/sonunda) ağırlıklı olarak kullanıyorsunuz? } \\
\text { Neden? }\end{array}$ & Ö & $\mathbf{f}$ & $\%$ \\
\hline Dikkat çekme amaçlı dersin başında kullanıyorum. & Ö4,Ö11,Ö12 & 3 & 27.27 \\
Konuya hazırlık amaçlı dersin başında kullanıyorum. & Ö1,Ö2,Ö9 & 3 & 27.27 \\
Toparlama amaçlı dersin ortasında kullanıyorum. & Ö5,Ö9 & 2 & 18.18 \\
Pekiştirme amaçlı dersin ortasında kullanıyorum. & Ö6,Ö10 & 2 & 18.18 \\
Tekrar amaçlı dersin sonunda kullanıyorum. & Ö7,Ö8,Ö11 & 3 & 27.27 \\
Değerlendirme amaçlı dersin sonunda kullanıyorum. & Ö1,Ö10 & 2 & 18.18 \\
\hline
\end{tabular}

Tablo 8.1'de öğretmenlerin "Bu teknolojileri dersin hangi aşamasında (başında/ortasında/sonunda) ağıllıklı olarak kullanıyorsunuz? Neden?" sorusuna verdikleri cevaplar gösterilmiştir. Tablo 8.1'e göre öğretmenler, öğretim teknolojilerini daha çok konuya hazırlık amaçlı dersin başında ve tekrar amaçlı dersin sonunda kullandıkları belirlenmiştir. Ö3 kodlu öğretmen, öğretim teknolojilerini derslerinde kullanmadığı için, bu soruya cevap vermemiştir.

Öğretmenlere, sınıf ortamında teknoloji kullanımlarına ilişkin öğrenci tutumlarının nasıl olduğunu belirlemeye yönelik Soru 8 yöneltilmiş ve veriler Tablo 9 'da sunulmuştur.

Tablo 9.

Öğretmenlerin "Soru 8"e Verdiği Cevaplar

\begin{tabular}{lccc}
\hline $\begin{array}{l}\text { Soru 8) Sizce, teknoloji kullanımınız öğrencilerin fen } \\
\text { bilimleri dersine katılımını ve derse ilgilerini nasıl etkiliyor? }\end{array}$ & ö & $\mathrm{f}$ & $\%$ \\
\hline Olumlu etkiliyor. & Ö1,Ö2,Ö4,Ö5,Ö6,Ö7, & 11 & 91.67 \\
& Ö8,Ö9,Ö10,Ö11,Ö12 & & \\
Olumsuz etkiliyor. & Ö3 & 1 & 8.33 \\
\hline
\end{tabular}

Tablo 9'da öğretmenlerin "Sizce, teknoloji kullanımınız öğrencilerin fen bilimleri dersine katılımını ve derse ilgilerini nasıl etkiliyor?" sorusuna verdikleri cevaplar sunulmuştur. Tablo 9'a göre Ö3 kodlu öğretmen teknoloji kullanımının öğrencinin fen dersine ilişkin ilgisini olumsuz etkilediğini belirtmiştir. Teknoloji kullanımının öğrencilerin fen dersine ilgi ve katılımını olumlu etkilediğini söyleyen öğretmenlerden Ö1,Ö4,Ö5 ve Ö7 kodlu öğretmenler görüşlerine ek olarak teknolojinin dozunda kullanılması gerektiğini belirtmişlerdir. Örneğin, Ö5 kodlu öğretmen fikrini "Sürekli kullanırsan çok ilgi çekmiyor. Çocuk ekrana doymuş, ona bakmak istemiyor. Etkinlikler daha çok ilgilerini çekiyor." şeklinde ifade ederken, Ö8 kodlu öğretmen "Teknoloji kullanımı, sanki çocukları o dünyanın, o ulaşılmaz dünyanın içine taşıyabiliyor, görseli yönünden de çok doyurucu." ifadelerini kullanmıştır. 
Öğretmenlerin teknoloji kullanımının öğretimin etkili gerçekleşmesinde faydalı olup olmadığına ilişkin görüşlerini belirlemek amacıyla öğretmenlere Soru 9 yöneltilmiş ve veriler Tablo 10 'da sunulmuştur.

Tablo 10.

Öğretmenlerin "Soru 9"a Verdiği Cevaplar

Soru 9) Öğretimin daha etkili gerçekleşmesinde teknoloji kullanımının faydalı olduğunu düşünüyor musunuz? Neden?

\begin{tabular}{lccc}
\hline Faydalı olduğunu düşünüyorum. & Ö1,Ö2,Ö4,Ö5,Ö6,Ö7, & 11 & 91.67 \\
& Ö8,Ö9,Ö10,Ö11,Ö12 & & \\
Faydalı bulmuyorum. & Ö3 & 1 & 8.33 \\
\hline
\end{tabular}

Tablo 10 'da öğretmenlere yöneltilmiş olan “Öğretimin daha etkili gerçekleşmesinde teknoloji kullanımının faydalı olduğunu düşünüyor musunuz? Neden?" sorusuna ilişkin cevapları verilmiştir. Tablo 10'a göre katılımc 12 öğretmenin, 11'i Soru 9'a olumlu cevap verirken, 1 öğretmen olumsuz cevap vermiştir. Öğretimin daha etkili olmasında teknoloji kullanımını faydalı bulan öğretmenlerden Ö6 kodlu öğretmenin neden faydalı bulduklarına ilişkin görüşleri "Çocuğun etkin olması açısından ve okullarda teknoloji kültürünün oluşması lazım." şeklindeyken, Ö1 kodlu öğretmen "Öğrencilerin dikkat süreleri düşük bu yüzden dikkatlerini çekiyor." ifadelerini kullanmış, Ö9 kodlu öğretmense "Görseli yönünden doyurucu." demiştir.

\section{TARTIŞMA VE SONUÇ}

Dördüncü sınıf, sınıf öğretmenleriyle yapılan mülakatta öğretmenlerin fen bilimleri dersi öğretim programı hakkında bilgi düzeylerini öğrenmeye yönelik sorulan soruya öğretmenlerin yarısından fazlası (\%66.68) fen bilimleri dersi öğretim programı hakkında bilgi sahibi olduklarını söylemişler ancak bu öğretmenlerin yarısı (\%33.34) istenilen açıklamaları yapabilmiştir. Bu da öğretmenlerin çok azının öğretim programı hakkında yeterli bilgiye sahip olduklarını göstermektedir. Verilere bakılarak bunun nedeninin programın yeni olması görülebilir. Örneğin Ö7 kodlu öğretmenin "Öğretim programı sürekli değiştiği için yeterli bilgiye sahip değilim. Sadece ön hazırlık yapıyorum, derse girmeden önce kazanımlara bir bakıyorum." ifadeleri, öğretmenlerin programın sürekli değişmesi sebebiyle program hakkında yeterli bilgiye sahip olmama nedenlerini açıklayabilir. Ocak'ın (2008) ve Öz'ün (2007) öğretmenlerin fen ve teknoloji dersi programına yönelik görüşlerini çeşitli değişkenlerle göre inceledikleri çalışmalarda genellikle öğretmenlerin program hakkında yeterli bilgiye sahip oldukları yorumuna ulaşılabilmesine karşın, Buluş Kırıkkaya'nın (2009) yaptığı çalışmada öğretmenlerin $\% 28$ 'inin program hakkında bilgi sahibi olmadıkları sonucuna ulaşmıştır. Ancak teknolojinin hızla geliştiği dünyamızda, bu gelişmelere ayak uydurmak için öğretim programlarının yenilenmesi ve geliştirilmesi bir gerekliliktir (Ayvacı ve Özbek, 2014; Ünal, Coştu ve Karataş, 2004). Bu sebeple öğretmenlerin program hakkında bilgi sahibi olmaları da gerekmektedir. Bu amaçla MEB'in öğretmenlere bu konuda hizmet içi eğitim semineri vermesi olumlu bir geri dönüş sağlayacaktır (Ünsal, 2013).

Öğretmenlerin fen bilimleri dersi öğretim programında yer alan öğrenme alanlarına yönelik bilgi düzeylerini belirlemeye amaçıı sorulan soruya öğretmenlerin büyük bir çoğunluğunun (\%66.67) öğrenme alanlarına ilişkin bilgilerinin olmadığı görülmektedir. Buna karşın öğretmenlerin diğer kısmıysa (\%33.37) içerik olarak bildiklerini ancak isim olarak bilmediklerini belirtmişlerdir. Bu sonuç Ayvacı, Ültay ve Mert'in (2012) çalışmalarıyla da paralellik göstermektedir. Bunun sebebi olarak öğretmenlerin programı benimseyemedikleri 
söylenebilir. Oysaki öğretim programlarının yürütücüsü olan öğretmenlerin programa hâkim olmaları, ders amaçlarına ulaşmalarında etkili bir faktördür (Serin, 2014).

Öğretmenlerin fen bilimleri dersi öğretim programı ile ders kitaplarının uyuşup uyuşmamasına yönelik görüşlerinin sorulduğu soruya öğretmenlerin çoğunluğu (\%58.33) programla kitabın uyuştuğunu belirtmiştir. Ancak örnek vermeleri istendiğinde yine büyük bir çoğunluğunun (\%41.67), ya örnek veremedikleri ya da çelişkili örnek verdikleri görülmektedir. Ö6 kodlu öğretmenin "Uyuşuyor ama kitabın daha zengin bilgilerle donatılmış, çocuğun seviyesine uygun olmasını isterdim. Kitapta konular çok dağınık, dolayısıyla yardımcı kitap kullanıyoruz. Ders kitabı, görseller ve bilgi yönünden zayıf kalıyor. Kitaba kalsak ulaşacağımız bilgi ve amaca ulaşmamız zor olur." örneğinde de olduğu gibi öğretmen programla kitabın uyuştuğunu söylemekte ancak devamında yanlış açıklamalar yapmaktadır. Bunun sebebi olarak öğretmenin programı yanlış değerlendirmesi ve uyuşma olarak öğretmenin sadece programda var olan ünitelerin kitapta da yer verilmesi şeklinde algıladığı düşünülebilir. Uyuştuğunu söyleyen öğretmenlerden Ö8 kodlu öğretmenin "Uyuştuğunu düşünüyorum. Yıllık programımıza, zaman çizelgemize baktığımda konu başlıklarının eş zamanlı gittiğini görüyorum." ifadeleri de bunu desteklemektedir. Fen Bilimleri dersi öğretim programıyla dersin kitabının uyuşmadığını söyleyen öğretmenler, uyuşmayan noktalara genel olarak programda istenen beceri ve davranışlar için yeterli etkinlik olmadığı ya da çok az yer verildiğini belirtmişlerdir. Örneğin Ö3 kodlu öğretmenin "Uyuşmuyor. Programda verilenler kitapta olmayabiliyor. Kitap hep sorularla geçiştiriyor, gereksiz ayrıntıda fazla." şeklinde düşüncelerini ifade etmiştir. Ders kitaplarında olması gereken nitelikler arasında, gereksiz, önemsiz, amaçsız içerik; yüzeysel, ön yargılı ve göz ardı edilen bilgiler olmamalıdır (Yılmaz, 2010). Özsoy'un (2007), ders kitaplarını öğretmen, öğrenci ve veli bağlamında değerlendirdiği yüksek lisans çalışmasında ders kitabıyla programın uyuştuğu ve ders kitaplarında gereksiz bilgi yoğunluğundan kaçınıldığı sonucuna ulaşmıştır.

Öğretmenlerin FTTÇ öğrenme alanı kapsamında, fen bilimleri dersi ders kitaplarında teknoloji tasarımı veya teknoloji uygulama etkinliklerine yönelik görüşlerinin alındığı soruda öğretmenlerin tamamı "Yeterli etkinlik yok." cevabını vermiştir. Bu sorunun opsiyonel sorusuna da öğretmenlerin tamamının "Bu tür etkinlikler gereklidir." cevabı verdiği görülmektedir. Neden gerekli olduğu hususunda öğretmenlere yöneltilen opsiyonel soruya öğretmenlerin \%50'sinin cevap veremediği görülmektedir. Diğer öğretmenlerse bu soruya farklı cevaplar vermiştir. Bu cevaplara bakıldığında öğretmenlerin çoğunluğunun, teknoloji tasarımına yönelik etkinlikleri yaparak yaşayarak öğrenmenin gerçekleşmesi için gerekli olduğu görüşünde birleştikleri görülmektedir. Kalıcı öğrenmenin, öğrencilerin derse aktif katılımlarını gerektirdiğini düşündüğümüzde, bu süreçte yaparak yaşayarak öğrenme uygulamaları gerekliliği ortaya çıkmaktadır (Gürol, 2003; Ültay, 2012). Örneğin Güneş ve diğerlerinin (2008) yaptıkları fen ve teknoloji ders kitapları hakkında sınıf öğretmenlerinin görüşlerini aldıkları çalışmalarında, kitaptaki deneysel etkinliklerin yeterli olmadığı sonucuna ulaşmışlardır. Bunun yanı sıra Gümüş ve diğerlerinin (2008) yaptıkları çalışmalarında da modelle öğrenmenin öğrenci başarısını arttırdığı sonucuna ulaşmışlardır.

Öğretmenlerin teknoloji tasarımlarına yönelik ödev/proje verip vermeme durumlarının araştırıldığı soruda öğretmenlerin büyük bir çoğunluğu (\%66.66) ödev verdiğini ifade etmiş ve ödev veren öğretmenlerin tamamının da araştırma ödevi verdiği tespit edilmiştir. Öğretmenlerin sadece araştırma ödevleri vermeleri nedenleri arasında zaman-malzeme yetersizliği, ödevleri velilerin yapması ve çocuğun bu ödevleri yapmaya vaktinin olmaması gibi sebepler görülmektedir. Örneğin Ö4 kodlu öğretmen düşüncelerini "Genellikle bu tür ödevlerin geri dönüşü \%10, geri kalanı ise velisine yaptırıyor." şeklinde ifade etmiştir. Ödev vermeyen \%33.34'lük kısımdaki Ö10 kodlu öğretmen "Ödev vermiyorum çünkü hem şuan ki konularda 
böyle bir ödev verebileceğimiz konu yok, hem de öğrencide fikir var ancak bunu yapmaya vakti yok." ifadelerini kullanmıştır. Ersoy ve Anagün'ün (2009) sınıf öğretmenlerinin fen ve teknoloji dersi ödev verme sürecine ilişkin öğretmen görüşlerini aldıkları araştırmada, ödev sürecinde tespit ettikleri 3 sorundan birini veli kaynaklı sorunlar, diğerini ise öğrenci kaynaklı sorunlar oluşturmaktadır. Buradan öğretmenlerin öğrencilere, bir yapı oluşturacak ödev vermekten ziyade, zaman olarak kısa sürede yapılabilecek ve öğrencilerin kendi başlarına yapabilecekleri araştırma ödevlerini daha pratik buldukları söylenebilir. Örneğin Deveci ve Önder'in (2014) fen ve teknoloji dersinde verilen ödevlere ilişkin öğretmen görüşlerini inceledikleri çalışmalarında, öğretmenlerin çoğunlukla araştırma ödevi verdikleri sonucuna ulaştıkları görülmektedir. Ödev/proje vermeyen öğretmenlerin neden ödev vermediklerini belirlemeye yönelik sorulan soruya öğretmenlerin yarısı, program içeriğine göre hareket ettikleri için vermediklerini belirtmişlerdir. Bu öğretmenlerden Ö7 kodlu öğretmenin soru 1'e verdiği cevaba bakarak, program hakkında bilgisinin olmadığını belirtmesi ve bu soruya program içeriğine göre hareket ettiği için ödev vermediğini belirtmesi, çelişkili cevap verdiğini göstermektedir. Bu durum öğretmenin program içeriği ile kitap içeriğini karıştırdığı sonucu ile açıklanabilir. Öte yandan, program hakkında yeterli bilgiye sahip olduğunu söyleyen Ö11 kodlu öğretmenin bu soruya verdiği cevapla tutarlılık gösterirken öğretmenin programın misyon ve amaçlarından kısmen haberdar olduğunu göstermektedir.

Ödev/proje veren öğretmenlerin ödevleri/projeleri ne amaçla verdiklerini belirlemeye yönelik sorulan soruya, öğretmenler teknoloji tasarımına yönelik araştırma ödevlerinde daha çok öğrenmeyi gerçekleştirmek ve öğrencinin derse olan ilgi ve olumlu tutumunu artırmak amaçlı ödev verdikleri görülmektedir. Bu cevabın eğitimin amaçları arasında olan, bireyde kalıcı davranış değişikliği oluşturmak, hedefine uygun düştüğü söylenebilir. Ödev/proje vermeyen öğretmenlerin, eğer ödev/proje verselerdi ne amaçla vermek isterlerdi sorusunun cevabını belirlemeye yönelik sorulan soruya öğretmenlerin yarısı "konuyla ilgili kazanıma ulaşmaları için" cevabını verdikleri görülmektedir. Ödev veren öğretmenlerin de ağırlıklı olarak "öğrenmenin gerçekleşmesi için" cevabı verdikleri düşünüldüğünde, öğretmenlerin bu tür ödevleri genel olarak kazanıma ve dersin hedeflerine ulaşmak için verdikleri söylenebilir. Deveci ve Önder'in (2014) yaptıkları çalışmada, öğretmenlerin fen bilimleri derslerinde ödevlerin öğretimsel amaçları olduğuna inandıkları sonucuna ulaşmışlardır. Ersoy ve Anagün'ün (2009) yaptıkları çalışmada, öğretmenlerin daha çok pekiştirme ödevi verdikleri sonucuna ulaşmışlardır. Öte yandan teknoloji tasarımlarına yönelik ödevlerin, fen ve teknoloji okuryazarı birey yetiştirme hedefleri doğrultusunda olması gerekli olduğu düşünülmektedir. Ayrıca fen bilimleri dersinde verilecek ödevlerin amacı öğrencilerin bilimsel süreç becerileri, özdisiplin, öz-güven ve öğrenme sorumluğu kazanmalarını sağlama olarak sıralanabilir (MEB, 2005; Ersoy ve Anagün, 2009).

Öğretmenlerin verdikleri ödevlerdeki/projelerdeki rollerini ve bu ödevleri/projeleri dersin değerlendirmesine dâhil edip etmeme durumlarını belirlemeye yönelik sorulan soruya öğretmenler verdikleri ödevlerde daha çok rehber olduklarını (\%62.5) ve dersin değerlendirmesine dâhil ettikleri veya performans davranışına yansıttıkları görülmektedir. Öğretmenlerin verdikleri ödevlerde rehber durumunda olmaları öğrenci merkezli yaklaşımı benimsediklerini gösterirken ödevlerde yönlendirici olarak rol alan öğretmenlerin davranışçı yaklaşımı benimsedikleri söylenebilir. Ödev/proje vermeyen öğretmenlerin eğer verselerdi, bu ödevlerde/projelerde rolleri ne olurdu ve ödevleri/projeleri dersin değerlendirilmesine dâhil ederler miydi, sorusunun cevabını belirlemeye yönelik sorulan soruya öğretmenlerin tamamının rollerinin rehber olacağını ve ödev/projeleri dersin değerlendirmesine katacakları cevabı verdikleri görülmektedir. Ödev veren öğretmenlerin cevaplarıyla bu bulgular karşılaştırıldı̆̆ında öğretmenlerin genel olarak rehber rolünde olmayı ve ödevleri ders değerlendirmesine katmayı tercih ettikleri söylenebilir. Bu bulgular yaş faktörüne göre 
yorumlandığında, rehber veya yönlendirici olma ile anlamlı bir farklılığın olmadığı söylenebilir. Ders içerisinde yapılan etkinliklerin eğitim hedeflerine ulaşıp ulaşmadığını belirlemede değerlendirme etkili bir faktördür (Çepni ve Akyıldız, 2009). Bu bağlamda öğretmenlerin teknoloji tasarımlarına yönelik ödevleri dersin değerlendirmesine katmalarını açıklamaktadır. Teknoloji tasarımlarına yönelik ödevleri performans davranışına yansıtan ve dersin değerlendirmesine katmayan öğretmenlerin notu bir tehdit olarak öğrencilere yansıtmayı istemedikleri için bu tür ödevleri sorumluluk duygusunu geliştirme amaçlı verdikleri belirlenmiştir. Ancak ödevlerde yönlendirici rolde olup dersin değerlendirmesine katmayan veya performans davranışı şeklinde yansıtan öğretmenlerin davranışçı yaklaşımı kısmen benimsedikleri söylenebilir.

Öğretmenlerin teknoloji alanındaki gelişmeleri takip etme düzeylerini belirlemeye yönelik sorulan soruya öğretmenlerin yarısına yakını teknolojiyi takip etmediklerini belirtmişlerdir. Yaş faktörü göz önüne alındı̆̆ında teknolojiyi takip etmeyle yaş arasında bir ilişkinin olduğu söylenebilir. Bu sonuç Akkoyunlu (2002) ve Özçelik ve Kurt'un (2007) çalışmalarıyla da paralellik göstermektedir.

Öğretmenlerin fen bilimleri dersi öğrenme ortamlarında (sınıf ortamında) hangi öğretim teknolojilerini kullandıklarını belirlemeye yönelik sorusuna bir öğretmen öğretim teknolojisi kullanmadığını belirtirken, kullanan öğretmenlerin tamamı bilgisayar ve projeksiyon kullandıklarını belirtmişlerdir. Ulaş ve Ozan (2010) ve Adıgüzel'in (2010) sınıf öğretmenlerinin eğitim teknoloji yeterliliklerini ve kullanma düzeylerini belirledikleri çalışmalarında, sınıf öğretmenlerinin sınıf ortamında bilgisayar teknolojilerini, internet temelli teknolojileri ve görsel-işitsel teknolojileri seyrek olarak kullandıkları ve bu teknolojilerin kullanımında istenilen yeterliğe sahip olmadıkları sonucuna ulaşmışlardır. Buna karşın çalışmaların yapııdığı yıl dikkate alındığında öğretmenlerin öğrenme ortamlarında teknoloji kullanımlarını arttırdıkları ve bunda da okulun teknoloji donanımı bakımından orta düzeyde olmasının etkili olduğu söylenebilir.

Kullanılan teknolojilerin dersin hangi aşamasında (başında/ortasında/sonunda) ağırlıklı olarak kullanıldığını belirlemeye yönelik yöneltilen soruya öğretmenlerin çoğunlukla dersin başında, dikkat çekme veya konuya hazırlık amacıyla cevap verdikleri görülmektedir. Görüp işittiklerimizin (\%50) duyduklarımıza (\%20) oranla daha akılda kalıcı olduğunu (Yiğit, 2009) düşündüğümüzde dikkat çekme ve konuya hazırlıkta görsel-işitsel teknoloji kullanımının önemli olduğu söylenebilir.

Öğretmenlerin, fen bilimleri dersinde teknoloji kullanımı öğrencilerin fen bilimleri dersine katılım ilgilerini nasıl etkilediğini belirlemeye yönelik sorulan soruya öğretmenlerin çok büyük bir çoğunluğu (\%91.67) olumlu yönde etkiliyor cevabını vermiştir. Bu bulgu, Akpınar ve diğerlerinin (2005) fen bilgisi dersinde öğretim teknolojisi kullanımına ilişkin öğrenci görüşlerini aldıkları çalışmada, fen bilgisi derslerinde eğitim teknolojisinin kullanılması, derse ilgiyi arttırma ve başarıyı arttırmaya olumlu katkı yaptığı sonucuyla benzerdir. Ayrıca Usta ve Korkmaz (2010), öğretmen adaylarının teknoloji kullanımına yönelik algılarını araştırdıkları araştırmada, öğretmen adaylarının eğitimde teknolojinin olumlu etkisine inançlarının yüksek olduğu bulgusuna ulaşmışlardır.

Öğretmenlerin büyük bir çoğunluğu (\%97.67) öğretimin daha etkili gerçekleşmesinde teknoloji kullanımının faydalı bulduğunu belirtmiştir. Faydalı bulunmasının nedenleri arasında, görsel doyuruculuğu, öğrencilerin yaşları itibariyle dikkat sürelerinin düşük olması bakımından dikkat çekici bulunması gibi öğretmen ifadeleri yer almaktadır. Eğitimin verimli olmasında eğitim teknolojilerinin sınıf ortamlarında kullanılması gerekliliği uluslararası düzeyde kabul edilmiş bir durumdur (Kurtdede Fidan, 2008). 


\section{5. ÖNERILER}

Araştırmanın sonuçlarına yönelik aşă̆ıdaki öneriler sunulmuştur:

- Sınıf öğretmenlerinin fen bilimleri dersi öğretim programı hakkında yeterli bilgiye sahip olmadıkları sonucu dikkate alındığında öğretmenlere, fen bilimleri dersi öğretim programının temel özelliklerine yönelik hizmet içi eğitim verilebilir.

- Öğretmenlerin teknoloji tasarım ve uygulama etkinliklerine daha fazla yer verebilmeleri için yeterli ders saati gereklidir. Bu etkinliklerin daha verimli ve etkili gerçekleşebilmesi için ilkokullardaki bir haftada okutulan üç saatlik fen bilimleri dersinin ders saati sayısı artırılabilir.

- Öğretmenlerin derslerinde öğretim teknolojilerini kullanabilmeleri, öncelikle çalıştıkları kurumun fiziksel imkanlarına bağlıdır. Bu sebeple eğitim-öğretim kurumları, öğretmenlerin ve öğrencilerin ihtiyaç duyabileceği öğretim teknolojileri ile donatılmalıdır. Bu bağlamda, MEB'in ilgili konulara ayırdığı bütçe artırılabilir.

- Öğretmenlerin güncel teknolojileri öğrenme ortamlarında kullanabilmeleri için bu konu kapsamında kendilerini geliştirip, teknolojik gelişimlere ayak uydurmaları gerekmektedir. Bu sebeple, sınıf öğretmenlerinin teknoloji tasarım/uygulama etkinliklerini verimli bir şekilde yürütebilmeleri için onlara bu etkinliklere yönelik kurslar verilebilir.

- Okutulan bir ders kitabı, o derse ait öğretim programının bir çıktısıdır ve birbirinden bağımsız düşünülemez. Bu sebeple, fen bilimleri dersi ders kitabı ile öğretim programı arasındaki uyuşmazlıklar dikkate alındığında, fen bilimleri dersi ders kitabı, dersin öğretim programına uygun ve öğrenci seviyesine göre yeniden düzenlenebilir.

- Fen ve teknoloji okuryazarı bireyler yetiştirebilmek için fen bilimleri dersi öğretim programındaki ilgili öğrenme alanı kapsamında ders kitaplarında da teknoloji uygulama ve tasarımlarına yönelik etkinlikler bulunması gerekmektedir. Bu kapsamda, etkili bir fen eğitimi için ders kitaplarında teknoloji uygulama ve tasarımlarına yönelik etkinliklerin sayısı artırılabilir.

\section{KAYNAKLAR}

AAAS. (1993). Science For All Americans: Project 2061. New York: Oxford University Pres.

Adıgüzel, A. (2010). Illköğretim okullarında öğretim teknolojilerinin durumu ve sınıf öğretmenlerinin bu teknolojileri kullanma düzeyleri. Dicle Üniversitesi Ziya Gökalp Eğitim Fakültesi Dergisi, 15, 1-17.

Akkoyunlu, B. (2002). Öğretmenlerin internet kullanımı ve bu konudaki öğretmen görüşleri. Hacettepe Üniversitesi Eğitim Fakültesi Dergisi, 22, 1-8.

Akpınar, E., Aktamış, H., \& Ergin, Ö. (2005). Fen bilgisi dersinde eğitim teknolojisi kullanılmasına ilişkin öğrenci görüşleri. The Turkish Online Journal Of Educational Technology, 4(1), 93100. 
Akpınar, Y. (2003). Öğretmenlerin yeni bilgi teknolojileri kullanımında yükseköğretimin etkisi: İstanbul okulları örneği. The Turkish Online Journal Of Educational Technology, 2(2), 7996.

Anagün, Ş. S. (2011). PISA 2006 Sonuçlarına göre öğretme-öğrenme süreci değişkenlerinin öğrencilerin fen okuryazarlıklarına etkisi. Eğitim ve Bilim, 36(162), 84-102.

Arslan, S., \& Özpınar, í. (2008). Öğretmen nitelikleri: İlköğretim programlarının beklentileri ve eğitim fakültelerinin kazandırdıkları. Necatibey Eğitim Fakültesi Elektronik Fen Ve Matematik Eğitimi Dergisi, 2(1), 38-63.

Aydın, B. (2003). Bilgi toplumu oluşumunda bireylerin yetiştirilmesi ve matematik öğretimi. Pamukkale Üniversitesi Eğitim Fakültesi Dergisi, 2(14), 183-190.

Aydın, F., \& Karaa, F. N. (2013). Öğretmen adaylarııın teknolojiye yönelik tutumları: Ölçek geliştirme çalışması. Türk Fen Eğitimi Dergisi, 10(4), 103-118.

Ayvacı, H. Ş., \& Er Nas, S. (2009). Öğretmen kılavuz kitaplarının yapılandırmacı kurama göre öğretmen görüşlerine dayalı olarak değerlendirilmesi. Necatibey Eğitim Fakültesi Elektronik Fen Ve Matematik Eğitimi Dergisi, 3(2), 212-225.

Ayvacı, H. Ş., \& Özbek, D. (2014). Fen bilimleri dersi 2013 öğretim programına yönelik öğretmen görüşleri (Ordu ili örneği). Milli Eğitim Dergisi, 204, 214-231.

Ayvacı, H. Ş., \& Şenel Çoruhlu, T. (2011). İlköğretim 7. sınıf fen ve teknoloji öğretmen kılavuz kitabının öğretmen görüşlerine dayalı olarak değerlendirilmesi. Erzincan Üniversitesi Eğitim Fakültesi Dergisi, 13(1), 25-37.

Ayvacı, H. Ş., Ültay, E., \& Mert, Y. (2012). 9. sınıf fizik öğretim programında yer alan teknoloji tasarım kazanımlarının uygulanabilirliğine yönelik öğretmen görüşlerinin belirlenmesi. Ondokuz Mayıs Üniversitesi Eğitim Fakültesi Dergisi, 31(1), 20-43.

Bağdatlı, A. (2005). Değişen ilköğretim programlarındaki 4. sınıf fen ve teknoloji dersinin taslak öğretim programının, öğrenci başarısına etkisi ve sınıf öğretmenlerinin programa ilişkin görüşlerinin değerlendirilmesi. (Yayımlanmamış Yüksek Lisans Tezi). Mustafa Kemal Üniversitesi Sosyal Bilimler Enstitüsü, Hatay.

Bakar, E., Keleş, Ö., \& Koçakoğlu, M. (2009). Öğretmenlerin MEB 6. sınıf fen ve teknoloji dersi kitap setleriyle ilgili görüşlerinin değerlendirilmesi. Ahi Evran Üniversitesi Kırşehir Eğitim Fakültesi Dergisi, 10(1), 41-50.

Buluş Kırıkkaya, E. (2009). İlköğretim okullarındaki fen öğretmenlerinin fen ve teknoloji programına ilişkin görüşleri. Türk Fen Eğitimi Dergisi, 6(1), 133-148.

Ceyhan, E., \& Yiğit, B. (2005). Konu Alanı Ders Kitabı Incelemesi (3. baskı). Ankara: Anı Yayıncilık.

Çepni, S. (2005). Araştırma ve Proje Çalışmalarına Giriş (2. baskı). Trabzon: Celepler Matbaacilık.

Çepni, S. (Ed.), Akyıldız, S. (Ed.), Baki, A., Ayas, A., \& Demircioğlu, G. (2009). Ölçme ve değerlendirme (1. baskı). Trabzon: Celepler Matbaacılık.

Çepni, S., Ayvacı, H. Ş., \& Bacanak, A. (2012). Bilim, teknoloji, toplum ve sosyal değişim (5. baskı). Trabzon: Celepler Matbaacılık.

Cohen, L., \& Manion, L. (1989). Research methods in education (4th ed.). New York: Routledge. 
Deveci, ì., \& Önder, í. (2014). Fen ve teknoloji dersinde verilen ödevlere yönelik öğretmen görüşleri. Illköğretim Online, 13(1), 33-47.

Dönmez Usta, N. (2011). Yapılandırmacı öğrenme kuramı çerçevesinde bilgisayar destekli öğretim materyali geliştirmesi, uygulanması ve etkililiğinin değerlendirilmesi: Çekirdek kimyası (radyoaktivite) örneği. (Yayınlanmamış Doktora Tezi). Karadeniz Teknik Üniversitesi Eğitim Bilimleri Enstitüsü, Trabzon.

Dönmez Usta, N. (2015). Fen bilgisi öğretmen adaylarının nükleer enerji farkındalığına bilgisayar destekli öğretimin etkisi. IV. Ulusal Kimya Eğitimi Kongresi, 7-10 Eylül 2015, Balıkesir.

Drew, C. J., Hardman, M. L., \& Hart, A. W. (1996). Designing and conducting research: Inquiry in education and social science (2nd ed.). Boston: Allyn and Bacon.

Ekiz, D. (2009). Bilimsel araştırma yöntemleri (9. baskı). Ankara: Anı Yayıncılık.

Erdoğan, M. (2007). Yeni geliştirilen dördüncü ve beşinci sınıf fen ve teknoloji dersi öğretim programının analizi: Nitel bir çalışma. Türk Eğitim Bilimleri Dergisi, 5(2), 221-259.

Ersoy, A., \& Anagün, Ş. S. (2009). Sınıf öğretmenlerinin fen ve teknoloji dersi ödev sürecine ilişkin görüşleri. Necatibey Eğitim Fakültesi Elektronik Fen ve Matematik Eğitimi Dergisi, 3(1), 58-79.

Eskicumalı, A., Demirtaş, Z., Gür Erdoğan, D., \& Arslan, S. (2014). Fen ve teknoloji dersi öğretim programları ile yenilenen fen bilimleri dersi öğretim programlarının karşılaştırılması. International Journal of Human Sciences, 11(1), 1077-1094.

Gömleksiz, M. N., \& Bulut, í. (2007). Yeni fen ve teknoloji dersi öğretim programının uygulamadaki etkililiğinin değerlendirilmesi. Hacettepe Üniversitesi Eğitim Fakültesi Dergisi, 32, 76-88.

Gümüş, İ., Demir, Y., Koçak, E., Kaya, Y., \& Kırıcı, M. (2008). Modelle öğretimin öğrenci başarısına etkisi. Erzincan Üniversitesi Eğitim Fakültesi Dergisi, 10(1), 65-90.

Güneş, M. H., Çelikler, D., \& Gökalp, M. (2008). İlköğretim I kademedeki yeni fen ve teknoloji ders kitapları konusunda sınıf öğretmenlerinin görüşleri. Çukurova Üniversitesi Sosyal Bilimler Enstitüsü Dergisi, 17(3), 193-210.

Gürol M. (2003). Aktif öğrenmeyi temel alan oluşturmacı öğrenme tasarımının uygulanması ve başarıya etkisi. Manas Üniversitesi Sosyal Bilimler Dergisi, 7, 169-179.

Huinker, D., \& Madison, S. K. (1997). Preparing efficacious elementary teachers in science and mathematics: The influence of methods courses. Journal of Science Teacher Education, 8,107-126.

İpek, C., Sağlam, H. İ., \& Duysak, A. (2007). Sınıf ve aday sınıf öğretmenlerinin yenilenen ilköğretim programlarına bakışı. Sakarya Üniversitesi Eğitim Fakültesi Dergisi, 14, 184197.

Kahyaoğlu, M. (2011). İlköğretim öğretmenlerinin fen ve teknoloji dersinde yeni teknolojileri kullanmaya yönelik görüşleri. Eğitim Bilimleri Araştırmaları Dergisi, 1(1), 79-91.

Kenar, ì. (2013). Fen öğretmeni niteliklerinin orta öğretimde öğrenci başarısına etkisi. Middle Eastern \& African Journal Of Educational Research, 5(6), 67-83.

Kurtdede Fidan, N. (2008). İlköğretimde araç gereç kullanımına ilişkin öğretmen görüşleri. Kuramsal Eğitimbilim Dergisi, 1(1), 48-61. 
Küçükahmet, L. (Ed.), Kılıç, Z., Atasoy, B., Tertemiz, N., Şeren, M., \& Ercan, L. (2001). Konu alanı ders kitabı inceleme kılavuzu: Fen bilgisi 4-8 (1. baskı). Ankara: Nobel Yayın Dağıtım.

Laçin Şimşek, C. (2009). Fen ve teknoloji dersi öğretim programları ve kitapları bilim tarihinden ne kadar ve nasıl yararlanıyor?. Ilköğretim Online, 8(1), 129-145.

Laçin Şimşek, C. (2010). Sınıf öğretmeni adaylarının fen ve teknoloji ders kitaplarındaki deneyleri bilimsel süreç becerileri açısından analiz edebilme yeterlilikleri. ilköğretim Online, 9(2), 433-445.

MEB. (2005). Illköğretim fen ve teknoloji dersi (4 ve 5. sınıflar) öğretim programı. Ankara: Talim ve Terbiye Kurulu Başkanlığı.

MEB. (2013). Fen bilimleri dersi (3-8. sınıflar) öğretim programı. Ankara: Talim ve Terbiye Kurulu Başkanlığı

Miles, M. B., \& Huberman, A. M. (1994). Qualitative data analysis (2nd ed.). California: Sage Publications, Inc.

Ocak, R. (2008). Ilköğretim 4. ve 5. sınıf fen ve teknoloji programının öğretmen görüşleri doğrultusunda değerlendirilmesi. (Yayımlanmamış Yüksek Lisans Tezi). Selçuk Üniversitesi Sosyal Bilimler Enstitüsü, Konya.

OECD (2013). Draft PISA 2015 science framework. Paris: OECD.

Öz, B. (2007). 2001 ilköğretim fen bilgisi dersi ve 2005 ilköğretim fen ve teknoloji dersi programlarına ilişkin öğretmen görüşleri. (Yayımlanmamış Yüksek Lisans Tezi). Çukurova Üniversitesi Sosyal Bilimler Enstitüsü, Adana.

Özçelik, H., \& Kurt, A. A. (2007). İlköğretim öğretmenlerinin bilgisayar öz yeterlikleri: Balıkesir ili örneği. Illköğretim Online, 6(3), 441-451.

Özdemir, O. (2010). Fen ve teknoloji öğretmen adaylarının fen okuryazarlığının durumu. Türk Fen Eğitimi Dergisi, 7(3), 42-56.

Özmen, H. (2004). Fen öğretiminde öğrenme teorileri ve teknoloji destekli yapılandırmacı (constructivist) öğrenme. The Turkish Online Journal of Educational Technology, 3(1), 100-111.

Özsoy, H. (2007). Ilköğretim 4-5. sınıf fen ve teknoloji ders kitaplarının öğrenci, öğretmen ve veli görüşleri bağlamında değerlendirilmesi. (Yayımlanmamış Yüksek Lisans Tezi). Zonguldak Karaelmas Üniversitesi Sosyal Bilimler Enstitüsü, Zonguldak.

Saban, Y., Aydoğdu, B., \& Elmas, R. (2015). 2005 ve 2013 fen bilgisi öğretim programlarının 4. ve 5. sınıf düzeylerinin bilimsel süreç becerileri açısından karşılaştırılması. Mehmet Akif Ersoy Üniversitesi Eğitim Fakültesi Dergisi, 15(32), 62-85.

Serin, G. (2014). Sınıf öğretmenlerinin fen ve teknoloji öğretim programını uygulama durumu ile fen eğitimine yönelik inançlarının uyumluluğu. Adıyaman Üniversitesi Sosyal Bilimler Enstitüsü Dergisi, 7(18), 741-774.

Şahin, i. (2008). Yeni ilköğretim birinci kademe fen ve teknoloji programının değerlendirilmesi. Milli Eğitim Dergisi, 177, 181-207.

Tekbıyık, A., \& Akdeniz, A. R. (2008). İlköğretim fen ve teknoloji dersi öğretim programını kabullenmeye ve uygulamaya yönelik öğretmen görüşleri. Necatibey Eğitim Fakültesi Elektronik Fen ve Matematik Eğitimi Dergisi, 2(2), 23-37. 
Timur, S., Karatay, R., \& Timur, B. (2013). 2005 ve 2013 yılı fen dersi öğretim programlarının karşılaştırılması. Adıyaman Üniversitesi Sosyal Bilimler Enstitüsü Dergisi, 6(15), 233-264.

Topal, N. (2009). 2004 fen ve teknoloji programının öğretmenler açısından değerlendirilmesi; Samsun örneği. (Yayımlanmamış Yüksek Lisans Tezi). Ondokuz Mayıs Üniversitesi Fen Bilimleri Enstitüsü, Samsun.

Toraman, S., \& Alcl, B. (2013). Fen ve teknoloji öğretmenlerinin yenilenen fen bilimleri dersi öğretim programına ilişkin görüşleri. EKEV Akademi Dergisi, 17(56), 11-22.

Tüysüz, C., \& Aydın, H. (2009). İlköğretim fen ve teknoloji dersi öğretmenlerinin yeni fen ve teknoloji programına yönelik görüşleri. Gazi Eğitim Fakültesi Dergisi, 29(1), 37-54.

Ulaş, A. H., \& Ozan, C. (2010). Sınıf öğretmenlerinin eğitim teknolojileri açısından yeterlilik düzeyi. Atatürk Üniversitesi Sosyal Bilimler Enstitüsü Dergisi. 14(1), 63-84.

Usta, E., \& Korkmaz, Ö. (2010). Öğretmen adaylarının bilgisayar yeterlikleri ve teknoloji kullanımına ilişkin algıları ile öğretmenlik mesleğine yönelik tutumları. Uluslararası insan Bilimleri Dergisi, 7(1), 1335-1349.

Ültay, N. (2012). Asit ve baz konusuyla ilgili REACT stratejisine ve 5E modeline göre etkinliklerin geliştirilmesi, uygulanması ve karşılaştırılması. (Yayınlanmamış Doktora Tezi). Karadeniz Teknik Üniversitesi Eğitim Bilimleri Enstitüsü, Trabzon.

Ültay, N., \& Çalık, M. (2016). A comparison of different instructional designs of 'acids and bases' subject. Eurasia Journal of Mathematics, Science and Technology Education, 12(1), 57-86.

Ünal, S., Çoştu, B., \& Karataş, F. Ö. (2004). Türkiye'de fen bilimleri eğitimi alanındaki program geliştirme çalışmalarına genel bir bakış. Gazi Eğitim Fakültesi Dergisi, 24(2), 183-202.

Ünsal, H. (2013). Yeni öğretim programlarının uygulanmasına ilişkin sınıf öğretmenlerinin görüşleri. Illköğretim Online, 12(3), 635-658.

Weis, A. H. (1999). Professional development: A link to better learning. School, Technology and Readiness Report. The Ceo Forum, Washington.

Yager, R. E. (1996). History Of Science/Tehcnology/Society as Reform in the United States. R. E. Yager (Ed.), Science/Tehcnology/Society as Reform in Science Education (pp. 3 -15), Albany: Suny.

Yeşilaydın, M. (2008). ilköğretim fen ve teknoloji dersi öğretim programına ilişkin sınıf öğretmenlerinin görüşleri. (Yayımlanmamış Yüksek Lisans Tezi). Eskişehir Osmangazi Üniversitesi Fen Bilimleri Enstitüsü, Eskişehir.

Yıldııım, A., \& Şimşek, H. (2011). Sosyal bilimlerde nitel araştırma yöntemi (8.baskı). Ankara: Seçkin Yayıncılık.

Yılmaz, M. F. (2010). Illköğretim dördüncü sınıf fen ve teknoloji ders kitabının öğretmen görüşlerine göre değerlendirilmesi. (Yayımlanmamış Yüksek Lisans Tezi). Afyon Kocatepe Üniversitesi Sosyal Bilimler Enstitüsü, Afyonkarahisar.

Yiğit, N. (Ed.), Alev, N., Özmen, H., Altun, T., \& Akyıldız, S. (2009). Öğretim Teknolojileri ve Materyal Tasarımı (4. baskı). Trabzon: Celepler Matbaacılık. 


\section{SUMMARY}

Technological designs as well as technological practices have impact on forming today's world in sociological systems. For instance, transformation of diskettes which we used at the beginning of 2000s, into data cards has allows us to store more information in smaller space and it has made our life easier. In this context, individuals who can devise technological designs and perform creative thinking along with individuals who can use technology have an important role in society's development and prosperity.

Raising technological literate individuals who can comply with today's technological world, is a significant necessity. For this reason, especially primary schools where basis of many talents, attitudes and manners is formed and primary teachers gain importance in this sense of raising these individuals. Taking into account that the basis of technology is depended on science; one of the key lessons of raising individuals who are science and technological literates is science lesson. When syllabus of primary school science lesson is examined it can be seen that there is an expression on 3th and 4th grades syllabus as "students are required to have knowledge, skill and perception." In this context, science school books of 3th and 4th grades have been examined and has been observed that these syllabuses fail to comply with general vision and aims. Subjects of the book stuck in the level of transferring only "knowledge", they fall short of obtaining technological practices and designs and learning domain of science-technology-society-environment and its sub-domains are hardly ever included in the school books. There are studies about syllabus and school books of science of 2015, and studies about technological practices and designs of Science school books of 2013 have not been encountered in the literature. Another significant factor of raising science literate individuals is the presence of technological practices and designs in the classroom environments. In this sense, implementation phase of the new science lesson's curriculum of 2013 carried out by teachers who are the operators of syllabuses and school books is highly significant. Because a program's success or failure is depended on how it is implemented. In this context, opinions of primary teachers' who are the operators of syllabuses and lessons, on technological practices and designs need to be taken because curriculum and school books of science lesson are new and there are gaps in the literature. For these reasons, the problem which has been searched in this study is 'what are the opinions of primary teachers on technological practices and designs?'

This is a qualitative study and method of case study which is a method of interpretive approach of research approaches has been used in this study. Population of this study includes primary teachers and 12 teachers who educate 4th grades and work at a public school on East Black Sea Region have been selected as samples. 7 teachers are women and 5 teachers are men. Their professional experience years range from 8 to 37. Semi-structured interview technique has been used in this study to collect data. Interviews have been made face to face with participants; each interview has taken 20-25 minutes time. Questions of interview which have been prepared to collect data are 9 basic questions. Data of interview which have been obtained via a voice recorder have been transcribed. Answers are tried to be described by detecting the critical answers and making required reductions three times in different times and places in order to raise persuasiveness and consistency of the study. Descriptive-interpretive analysis has been implemented on the data. Questions of interviews which have been formed by the researcher before the progress of collecting data has started, have been controlled by a course training specialist in order to provide their credibility of aspect and scope and by a Turkish linguist to provide comprehensibility. Required arrangements have been made in accordance with the opinions of the specialists.

In the light of the data obtained, it has been observed that very few of the classroom teachers have enough information about the curriculum. It has been ascertained that all the teachers who give assignments related to technological designs give search assignments. Some of the reasons why teachers give only search assignments are claimed to be that parents do the assignments; children do not have time to do them and the lack of time-material. Teachers, who do not give assignment/project, have stated that they do not give assignment/project since they act in accordance with content of the curriculum. It has been observed that teachers who give assignment/project aim to achieve learning more and to increase the interest and positive manner of the student towards the lesson. Teachers have 
stated that they mostly provide their guidance on the assignments/projects they give and they include them in evaluation of the lesson or they reflect them on performance manner. Teacher who do not give assignment/project have stated that if they had given these assignments/projects they would have considered these in the evaluation of the lesson. Half of the teachers have stated that they do not follow the developments in the area of technology. Taking into account the age variable, is can be said that there is a relation between act of following the technological developments and the age. Majority of the teachers have stated that they use computer and projection as learning technology in the class environment. It has been ascertained that teachers use learning technologies in the beginning of the lesson in order to get attention and to provide provision of the subject. Great majority of teachers have given the answer that technology usage in the science lesson influence students' attendance and interests towards the lesson positively.

In the light of these results, some suggestions have been made as the following:

Weekly course hours of the science lesson which are now only 3 should be increased, educational institutions should be equipped with the learning technologies which teachers and students may need and classroom teachers should be provided courses with regard to the activities of technological design/practice to carry out these activities more efficiently. 